\title{
Marriage Delayed and Equalized: Effects of Early U.S. Compulsory Schooling Laws on Marital Patterns by Race
}

\author{
Emily Rauscher \\ University of Kansas \\ Department of Sociology \\ 716 Fraser Hall \\ 1415 Jayhawk Blvd. \\ Lawrence, KS 66045 \\ emily.rauscher@ku.edu
}

\begin{abstract}
Identifying a causal relationship between education and marital status poses methodological challenges. Using regression discontinuity analyses of U.S. Census data from 1910 and 1930, I estimate effects of early U.S. compulsory schooling laws on marital patterns by gender and race. Results from 1910 suggest compulsory laws had heterogeneous effects by race and gender, reducing the likelihood of being married only among non-white men. Results from 1930 suggest compulsory schooling decreased the racial gap in likelihood of being married and in age at first marriage by at least $24 \%$. Contemporary implications include potential benefits of extended compulsory schooling for racial equality.
\end{abstract}

Keywords: education; inequality; marriage; race; compulsory schooling Acknowledgements: I am grateful to anonymous reviewers, who provided valuable feedback. 


\section{Introduction}

Marital patterns have gained increasing attention in recent decades for the central role they play in inequality - particularly among children (Wu and Wolfe 2001; Ellwood and Jencks 2004; McLanahan 2004; Looney and Greenstone 2012; Thompson 2013; Greenwood et al. 2014). Attempts to understand unequal marital patterns focus on economic standing (Sweeney 2002; Goldstein and Kenney 2001; Oppenheimer et al. 1997; Lloyd and South 1996;

Goldscheider and Waite 1986), yet certain aspects of economic standing may be more important - and amenable to policy change - than others. Educational expansion, for example, may improve both educational and marital equality by race and thereby provide a policy lever to reduce racial childhood inequality.

While some research has investigated racial heterogeneity in the relationship between education and marriage (Goldstein and Kenney 2001; Sweeney 2002; Bennett et al. 1989; Oppenheimer et al. 1997), few have explicitly questioned the equalizing potential of education for marriage outcomes by race. Raising the minimum level of schooling should increase equality in education by race, because a higher proportion of non-white students drop out of school than white students (Kena et al. 2015). If extended compulsory schooling increases educational attainment more among non-whites, it could similarly change marital patterns (e.g., prevalence and timing) more among non-whites, with tremendous implications for policy efforts to increase racial equality among future generations.

Despite the potential of such policy changes, demographic research has difficulty distinguishing between effects of education and cohort or other changes. To address these issues, this paper capitalizes on state differences in the timing of early compulsory schooling 
laws to ask whether educational expansion increased equality of marital patterns - including prevalence and timing - by race.

In his January 2012 state of the union address, President Obama urged states to extend the length of compulsory schooling to age 18. Politicians typically use the economy and international competitiveness to justify such educational expansion efforts. Education contributes to economic growth (Lutz and Samir 2011; Lutz et al. 2008), but it is likely to have other demographic consequences as well, including effects on marital patterns. While the effect of turn-of-the-century educational expansion on marriage is of interest to help understand demographic change and inequality, it also offers some contemporary implications, discussed in the conclusion.

In the following section, I provide background information on early U.S. compulsory schooling laws, followed by empirical and theoretical background, details on methods and analyses, and a conclusion that discusses implications and raises future questions.

\section{Background}

\section{Compulsory Schooling Laws}

In 1852, Massachusetts was the first state to require school attendance. Before this law, only youth working in certain types of jobs were required to attend school. With varying degrees of speed, all states eventually followed Massachusetts and, by 1918 when Mississippi required attendance, all states (with the exception of Alaska, which did not join the union until 1959) had passed a compulsory schooling law. The timing of the first compulsory school attendance law in each state is provided in Table S1. Before these early compulsory laws, only certain youth working in particular jobs were required to attend school. The laws did not include any requirement to complete a certain number of grades, only to attend school at specified ages, 
typically ages 8 to 14 (Steinhilber and Sokolowski 1966). As noted by Rauscher (2014), these compulsory laws targeted lower class and immigrant families, whose children were less likely to attend school. Thus, they explicitly aimed to increase equality of school attendance.

While some research suggests these early compulsory schooling laws had little effect on overall school attendance rates (Landes and Solmon 1972; Goldin and Katz 2011), research using more sophisticated techniques suggests otherwise (Puerta 2009). Specifically, county-level difference-in-differences analyses indicate that early compulsory laws increased attendance rates by approximately 7\% (Puerta 2009). Furthermore, studies investigating heterogeneous effects find that the laws increased equality of school attendance and educational attainment by race and class (Puerta 2009; Rauscher 2014). These heterogeneous effects are expected because compulsory schooling laws represent an effort to raise the minimum level of education; therefore, they should have the strongest impact on those least likely to attend school. In other words, they should have a stronger effect on non-white than white children. Similarly, any contemporary extension of the compulsory schooling age would likely have the strongest impact on those most likely to leave school early - lower-income and minority students. State-level variation in the timing of early compulsory schooling laws provides a unique opportunity to investigate effects of raising the minimum level of education on marital patterns. Importantly, the laws increased school attendance and educational attainment among non-whites more than whites (Puerta 2009; Rauscher 2014), suggesting they may similarly have affected marriage patterns more among non-whites than whites.

\section{$\underline{\text { Education and Marital Patterns }}$}

A long line of research investigates the relationship between economic standing - of men, women, or both - and marriage. Studies provide convincing evidence of this relationship, partly 
by using multiple measures of economic standing, including education, earnings, employment status, career entry difficulty, and homeownership (Sweeney 2002; Goldstein and Kenney 2001; Oppenheimer et al. 1997; Lloyd and South 1996; Bennett et al. 1989; Goldscheider and Waite 1986). Education, however, impacts multiple aspects of our lives and its distinct consequences for marriage patterns deserve further investigation.

While education certainly improves economic standing, it has other individual and social implications as well. Existing research on the relationship between education and marriage tends to examine education as one measure of or a proxy for economic standing (e.g., Goldstein and Kenney 2001), rather than an independent contributor to marital patterns. While evidence consistently suggests a positive relationship between men's economic prospects and their likelihood of marriage (Sweeney 2002; Cooney and Hogan 1991; Goldscheider and Waite 1986; Oppenheimer et al. 1997), it is difficult in some cases to tease out education-specific effects. For men, studies that examine education suggest a nonlinear relationship between schooling and marriage. That is, white men with low (less than 12 years) and high levels of education are more likely to marry than others (Oppenheimer et al. 1997; Oppenheimer and Lewin 1999).

In contrast to men, evidence suggests women's relationship between education and marriage changed over time (Goldstein and Kenney 2001). In recent decades, the relationship between education and marriage has been similar to that of men, with highly educated women being more likely to marry (Goldstein and Kenney 2001; Sweeney 2002; Isen and Stevenson 2010). Earlier in the 20th century, however, highly educated women faced a marriage penalty (Cookingham 1984). This "penalty" could reflect distaste for educated women among men, but could also reflect economic independence if education provides women more choice in whether or not to marry (Waite and Spitze 1981; Preston and Richards 1975). Regardless of the 
explanation, gender differences in the relationship between education and marriage in the early 1900s imply that compulsory schooling laws may have influenced the marital patterns of men and women differently.

Education and Marital Inequality

Importantly, the education-marriage relationship may also differ by race. While some research finds largely similar education-marriage relationships by race (Goldstein and Kenney 2001; Sweeney 2002), others find important differences (Bennett et al. 1989). For example, Oppenheimer and colleagues (1997) find that, contrary to the nonlinear pattern among white men, black men experience a consistently positive relationship between education and marital chances. Thus, because of the linear relationship between education and marriage and because the early compulsory schooling laws increased attendance and educational attainment more among non-white than white men (Puerta 2009; Rauscher 2014), the laws may have increased the likelihood and altered the timing of marriage more among non-white than white men.

Similarly, because black women have historically had higher rates of labor force participation than white women (Goldin 1990), the education-marriage relationship may also differ by race among women. For example, economic independence was already high among black women and could have been further developed with more education. In light of differences in labor force participation and because the early compulsory schooling laws increased schooling more among non-white than white women, the laws may have influenced the likelihood and timing of marriage more among non-white than white women.

In recent decades, white adults in the U.S. are more likely to have married at some point in their lives, and at an earlier age, than blacks (Elliott et al. 2012). In the early 1900s, however, the opposite was the case: black men and women were more likely to have married and at 
younger ages, on average, than white men and women (Elliott et al. 2012). In the context of the early 1900s and stronger impacts of the laws on non-white children, $\underline{\text { Hypothesis } 1}$ is that compulsory schooling increased age at marriage more among non-white than white men and women, thus increasing racial equality in marital timing.

If education increased one's appeal on the marriage market, being required to attend school could have increased the likelihood of being married and reduced the likelihood of never having married. Because the laws impacted non-white more than white children, we might expect compulsory laws to increase the likelihood of marriage more among non-whites. On the other hand, compulsory schooling laws may have made non-whites less likely to marry - by further increasing the economic independence of non-white women or encouraging the marital patterns of their white counterparts at the time, for example. In that case, compulsory schooling may have reduced the likelihood of being married more among non-whites, and thereby increased racial equality in likelihood of marriage.

Effects of the compulsory laws on racial inequality in the likelihood of marriage are difficult to predict. However, because the early compulsory schooling laws increased racial equality in education (Rauscher 2014; Puerta 2009), Hypothesis 2 is that the compulsory schooling laws also increased racial equality in the likelihood of being married and never having married.

Because a higher proportion of non-white students drop out of school than white students (Kena et al. 2015), compulsory schooling laws offer one way to increase equality of educational attainment by race. Investigating effects of an early instance of this equalizing policy will shed light on the potential role of education in reducing marital inequality by race and whether the relationship differs by gender. Marital patterns have gained increasing attention in recent 
decades for the central role they play in childhood inequality (McLanahan 2004). While some research has investigated racial heterogeneity in the relationship between education and marriage, little research has explicitly questioned the equalizing potential of education for marriage outcomes by race. If raising the minimum level of schooling could increase equality in marital patterns by race, it would offer one policy tool to increase racial equality among future generations.

\section{The Potential Importance of Education for Marital Patterns}

If education increases marital equality, it raises questions about how this process occurs. Education could impact the likelihood or timing of marriage through economic or labor market potential (Chiappori et al. 2009) but also through other mechanisms, such as self-actualization (Lesthaeghe 2007), altered beliefs or values, raised aspirations, institutionalization of the life course, or facilitation of interactions between potential spouses. Related to institutionalization of the life course, women are likely to delay marriage until after completing their schooling (Blossfeld and Huinink 1991), so educational expansion could also delay marriage by pushing back the normative age at which individuals are available to marry. Thus, there are multiple mechanisms through which education could influence marital timing. This study will not attempt to adjudicate among these mechanisms or to estimate the direction of their potential effects; it only attempts to estimate the relationship between compulsory education and marital patterns in a situation which allows distinguishing between cohort and educational changes.

Because education could delay marriage (Blossfeld and Huinink 1991), the relationship between compulsory schooling and marital status could differ depending on which point in the life course is examined. Specifically, results could be weaker earlier in the life course and stronger at later ages. For this analysis, the implications are that estimated effects of compulsory 
schooling laws on marital patterns may be weaker when examining earlier time periods (1910), because the cohorts of interest are younger. In contrast, when examining later time periods (1930), the estimated effects may be stronger because potential differences in marital patterns have had time to emerge.

A further concern relates to potential heterogeneity. The relationship between schooling and marriage depends on other economic measures, which partly supports the use of education as a proxy for economic standing. According to research by Harknett and Kuperberg (2011:57), for example, "educational differences in marriage would largely disappear if labor market conditions for different education groups were equalized." However, education - particularly compulsory schooling requirements - tends to be more amenable to policy changes than other aspects of economic standing. Oreopoulos (2009), for example, shows a great deal of variation in the length of state compulsory schooling over recent decades in the U.S. Those on both sides of the political divide seem relatively open to changes in minimum educational requirements while minimum wage, minimum basic income, and other economic policy changes spur more heated debates.

Research that has examined the relationship between education and marital patterns establishes an associational rather than a causal relationship. Comparing cohorts at the national level (e.g., Sweeney 2002) can document change over time, but cannot isolate the effect of education from other changes that occurred in the same time period and may also have contributed to marital change. For example, age at first marriage declined fairly steadily from 1900 to 1960 (Haines 1996) while educational attainment increased steadily during the same period (Goldin and Katz 2008). Although these national trends do not support arguments that education delays marriage, they do not refute them either. Any delaying effects of educational 
expansion may simply have been overpowered by other changes (e.g., in the economy). Causal inference techniques allow a more precise estimate of the relationship between educational expansion (specifically, compulsory schooling laws) and marriage. By capitalizing on state variation in the timing of early compulsory schooling laws, I am able to approach a causal estimate of the relationship between educational expansion and marital patterns, while controlling for cohort, state, and other differences.

\section{Data, Measures, and Analytic Strategy} Data

I use Integrated Public Use Microdata Series (IPUMS; Ruggles et al. 2015) census data from the years 1910 and 1930 to investigate compulsory schooling effects on marital patterns. While most census years include current marital status information, marital timing provides more information (i.e. flow) than simply whether an individual was married at the time of the census in a particular year (stock). Among the census years that include cohorts covered by the early compulsory laws, only 1930 and 1940 include age at first marriage. The 1940 census, however, only includes this information for women, which prevents gender comparisons and is therefore not used. The 1900 and 1910 censuses include duration of current marital status, but only the 1910 census provides information about number of marriages to rule out the possibility that duration of current marriage measures the length of a second or higher order marriage. Thus, the 1900 census is not used, although sensitivity analyses of pooled 1900 and 1910 census data without excluding remarried individuals yield similar results.

I limit analyses to those who were born in the U.S. and who were age 15 or above at the time of the 1910 and 1930 censuses. I exclude foreign born individuals because I am unable to determine whether or for how long they were in the U.S. during their childhood and, therefore, 
whether they were subject to a compulsory schooling law. I exclude those under age 15 because compulsory schooling laws in most states required attendance until age 14 (Steinhilber and Sokolowski 1966) and because those under age 15 are unlikely to be married or even on the marriage market. In fact, marital status is only recorded for those ages 12 and over in the 1910 and 1930 censuses and mean age at first marriage in 1910 was approximately 23 and 27 for women and men, respectively (22 and 26 in 1930) (Haines 1996:23).

Preliminary analyses (available upon request) use proportional hazard models to predict when each state passed its first compulsory schooling law; these analyses identified state-level measures that best explain variation in the timing of these laws. All models shown control for those measures, including proportion illiterate (associated with later laws), proportion employed in manufacturing, proportion of prisoners who are non-white, and incarceration rate (per 100,000 people) (all associated with earlier laws). I also control for proportion foreign born because reports at the time suggest compulsory laws were aimed at immigrant children (Commissioner of Education 1891; Moore 1902). Sensitivity analyses controlling for additional state-level measures (including proportion of adjacent states with the law, proportion elderly, proportion urban, male unemployment rate, and manufacturing production per employee, all associated with earlier laws, and Democrat governor and proportion black, associated with later laws) yield similar results. The state-level data are collected from aggregated micro-level census data, a compilation of statistical abstracts (U.S. Census Bureau 1975), ICPSR Historical Census Data 1790-1970 (ICPSR 1970), and Behrens et al. (2003), who generously provide incarceration data.

\section{Measures}

Marital outcomes are measured in several ways. In both 1910 and 1930, marital status is measured as indicators for whether an individual: 1) has never been married, or 2) is currently 
married and living with his or her spouse. The married indicator codes as zero those who are separated from their spouse because, if marital benefits such as improved economic standing, health, and happiness accrue to those living with their spouse (Avellar and Smock 2005; Gilbert 2005; Murray 2000), separation does not provide those benefits and could indicate de facto divorce. I include both of these indicators (never married and currently married) because of expected racial and gender differences in the longevity of one's spouse. For example, women and whites lived longer on average than men and blacks in the early 1900s. According to the National Center for Health Statistics (2014:85), overall life expectancy at birth was 47 years in 1900, but women (48 years) had higher life expectancy than men (46 years) and whites (48 years) were expected to live longer than blacks (33 years) (NCHS 2014:85). Given these differences, examining differences in the likelihood of both currently and never married provides a more complete picture.

Marital timing is measured differently in 1930 than in 1910 due to changes in the census. In 1930, marital timing is measured by age at first marriage. This 1930 census question was limited to those ages 12 and over who were currently married. Models predicting age at first marriage in 1930 are fitted in two ways: 1) coding those who have never married as 0 on age at first marriage and controlling for whether an individual has never married (i.e. the missing indicator method); and 2) excluding those who have never married. Results of both approaches yield consistent results and only those of the first approach are presented.

Marital timing is unavailable for divorced or widowed individuals, which likely excludes a higher proportion of people as age increases. I therefore also investigate marital timing in 1910, when the first cohorts affected by the compulsory laws were younger. For individuals who were currently married in 1910, the census recorded the length of that marriage in years. By 
subtracting the length of current marriage from age, I calculate a measure of age at marriage. Unfortunately, this measure includes remarried individuals and therefore measures age at first marriage with error. The 1910 census also includes information about whether an individual has remarried. In the full 1910 sample, $8 \%$ of women and 12\% of men are remarried. By limiting analyses of this calculated age at marriage measure to those who have been married only once, I am able to measure age at first marriage. Thus, estimates for age at first marriage in 1910 are only valid for those who are currently married and have never remarried. While this is not ideal, individuals within a narrow window of the compulsory cutoff are younger in 1910 than they would be in later censuses and therefore have had less time to be widowed, divorced, or remarried. Nevertheless, it is important to remember that marital timing results for 1910 are only valid for those who were currently in their first marriage.

Compulsory assignment is an indicator for whether an individual was ever required to attend school. Based on state and year of birth, state year of compulsory schooling law, and the ages each state required school attendance, compulsory assignment represents an external influence on whether and for how long an individual attended school as a child. For example, if an individual was born in Iowa in 1886, she would have been 16 years old in 1902, when Iowa made school attendance compulsory. She would not have been required to attend school because she was past the compulsory school age. If her brother, however, was born in 1889 , he would have been 13 years old when the law was passed and required to attend school (if only for one year). These two hypothetical individuals would be 44 and 41 in 1930 (24 and 21 in 1910).

If a family moved to another state between an individual's birth and school attendance age, then this measure of compulsory assignment may be incorrect. Thus, compulsory assignment is measured with some error, which could lead to attenuation bias. Results may 
therefore underestimate compulsory effects. However, state of birth is a better estimate of where an individual lived during childhood than current state of residence in adulthood. Interstate migration rates were lower in the early 1900s than they are today (Molloy et al. 2011), and interstate migration among families with children was likely lower than the overall rate.

While the law in most states required attendance of those ages 8 to 14 (Steinhilber and Sokolowski 1966), the laws of a few states required attendance of older children (age 15 in Maine, Rhode Island, Wisconsin; age 16 in Connecticut, Minnesota, New Hampshire, Wyoming). As noted by Rauscher (2014), the law in some states went into effect the year after it was passed and, even without that delay, many children would be a year older by the start of the next school year. Therefore, individuals are not considered part of the compulsory group (i.e. are coded zero for the compulsory assignment indicator) if, in the year the law was passed, they were already the maximum age required to attend (e.g., age 15 in Maine). All individuals who were at least one year below the maximum age at the time of the law were legally required to attend school for at least one school term and are therefore included in the compulsory group (i.e. coded one for the compulsory assignment indicator). Educational attainment is not available in the 1910 or 1930 censuses and is not measured in this study, but existing research suggests early compulsory schooling laws increased attendance rates as well as equality of school attendance and educational attainment by race (Puerta 2009; Rauscher 2014).

I create a measure of age at the time of the law, centered at the oldest age required to attend (the compulsory age cutoff) in one's state of birth. This measure of age at the time of the law, called compulsory cohort, is the forcing variable that assigns individuals to the compulsory or non-compulsory group. I control for this measure in all regression discontinuity models to account for any marital differences by compulsory cohort (age at the time of the law). Because 
the timing of the law varies by state, this measure is distinct from birth cohort, allowing me to control for cohort categories in models and distinguish between changes in marital patterns by cohort and the compulsory laws.

To investigate whether the laws promoted marital equality by race, compulsory assignment is interacted with an indicator for non-white race. On this indicator, whites are coded zero and those in all other categories are coded one. Black individuals make up the vast majority of the non-white group (98.5\% in 1910; 97.3\% in 1930). Other groups in the 1910 and 1930 censuses include American Indian, Chinese, Japanese, and other Asian or Pacific Islander. Sample sizes for these groups are too small, however, to allow separate analyses and they are all included in the non-white category. Although Asians and American Indians are included in the non-white indicator, results largely reflect black-white differences, since blacks make up the vast majority of the non-white group.

Research on social fluidity suggests that individual racial classification can change over time, depending on factors such as perceived success or occupational status (Saperstein and Penner 2012; Freeman et al. 2011). These within-person changes in racial categorization also occurred in census data from 1870 to 1920 (Saperstein and Gullickson 2013). For this study, evidence of social fluidity means that individuals may be misclassified in the census data, with a greater likelihood of classifying those with higher status or more education as white. This could lead to an overestimation of racial inequality of marital status in these analyses. However, compulsory assignment is random with respect to race, so estimated effects of compulsory schooling would not be biased by this error. Furthermore, assuming misclassification by race is relatively constant over time, estimated effects of compulsory assignment by race should also not be biased. 
Control variables include non-white, age (up to a quartic), state of birth indicators, cohort indicators (measured in five-year intervals), and the state measures that best explain variation in the timing of compulsory laws. Linked to each individual based on state of birth and the census year when the individual was closest to age 10 , these measures help address potentially important state differences during one's childhood. They include the state proportion employed in manufacturing, illiterate, foreign born, and incarcerated (per 100,000 residents), as well as the proportion of prisoners who are non-white.

\section{Analytic Strategy}

Naive analyses of the relationship between education and marriage may yield spurious estimates because individual characteristics such as dependability or motivation, among other things, may influence both education and marriage outcomes. To better estimate the educationmarriage relationship, I use cohort differences in exposure to compulsory schooling laws and state differences in the timing of laws to identify effects of educational expansion, controlling for age and cohort differences. Individuals, particularly children who are unable to decide where they live, cannot choose whether or not they are required to attend school. Thus, at the individual level, the timing of state compulsory schooling laws is exogenous with respect to marriage outcomes. Capitalizing on these exogenous differences in compulsory assignment, I compare those just under or just over the compulsory cutoff to estimate effects of compulsory education laws on marital outcomes.

An intent-to-treat estimate compares individuals who were assigned to the treatment (in this case, adults who were required to attend school as children) to those who were not assigned to the treatment (not required to attend school), regardless of compliance (whether or not they actually attended). By including all targeted individuals, the intent-to-treat estimate remains 
unbiased to heterogeneous responses to treatment assignment or non-compliance (Freedman 2006). For example, individuals who would not attend school regardless of being required may have other disadvantages - such as poverty or disability - that could also impact their likelihood or timing of marriage. Similarly, those who attend regardless of compulsory assignment may be more likely to marry for reasons other than education. Finally, being required to attend may perversely encourage some, who would have attended otherwise, to work instead (e.g., if the law increased demand for child laborers). These defiers would bias an instrumental variable (or treatment-on-the-treated) estimate. An intent-to-treat estimate is robust to these heterogeneous responses and also allows compulsory laws to influence marital status or timing through mechanisms other than school attendance or educational attainment (Freedman 2006).

To provide a complete picture of the effects of compulsory laws on marital patterns, the Appendix provides results of regressions including the full sample, which includes cohorts born many years before or after the compulsory law, separately by gender and year. These estimates include the largest possible sample and improve on existing research by examining differences by compulsory assignment controlling for cohort and state differences, but they could still reflect other differences because they include individuals far from the compulsory cutoff.

The main analyses rely on more precise estimates using a regression discontinuity (RD) approach. The RD sample is limited to those within 5 years on either side of the compulsory assignment cutoff and the model controls for compulsory cohort (the forcing variable, which measures age at the time of the law in one's state of birth) and compulsory cohort interacted with compulsory assignment. To take the example of Iowa, which required attendance in 1902, the RD sample would include those born between 1884 and 1893 (ages 17-26 in 1910 and ages 3746 in 1930). In 1910, the RD sample in states with later compulsory laws would further exclude 
those born after 1895 , because later cohorts would not have reached age 15 in 1910 . In New Jersey, which made attendance compulsory in 1875 , the RD sample would include those born between 1857 and 1866 (ages 44-53 in 1910 and 64-73 in 1930). The main analyses are limited to those within 5 years on either side of the compulsory assignment cutoff. However, sensitivity analyses including those within 10 years of the cutoff yield consistent results (provided in the Appendix).

By excluding those farther from the cutoff and limiting other unobserved differences between those required or not required to attend school, RD estimates provide a more precise estimate than those based on the entire sample. Within a narrow window on either side of the compulsory cutoff, individuals should be similar except for observed differences in the forcing variable (included as a control) that assigns individuals to the treatment group (Lee and Lemieux 2010; Imbens and Lemieux 2008; Lee and Card 2008). Key assumptions of this RD approach include: 1) within a narrow window on both sides of the compulsory assignment cutoff, there are no meaningful unobserved differences between treatment groups; and 2) any remaining factors related to marital patterns vary continuously by age at the time of the law, which is controlled in the regression (Lee and Lemieux 2010: 287).

I check the validity of the RD approach by looking for discontinuities in frequency and other measures by the forcing variable. Discontinuities in the density of the forcing variable might suggest that some individuals were able to manipulate themselves around the cutoff (McCrary 2008), by lying about their age, for example, to avoid being required to attend school. If that were the case, compulsory assignment would no longer be exogenous. If other variables that should be unrelated to the forcing variable show discontinuities at the compulsory cutoff, this would inspire doubt about the RD assumptions. In support of the validity of the RD 
approach for this analysis, I do not find evidence of sharp discontinuities at the compulsory cutoff. Graphs checking for discontinuities in the density of the forcing variable and two other measures - proportions foreign born and employed in manufacturing - are included in the Appendix Figures S1-S6.

Figures 1 and 2 examine the relationship between the forcing variable and marital status separately by race. More than a sharp discontinuity in the outcome variables, these graphs suggest that the relationship between cohort and marital status changed with the laws, particularly among non-whites. Because of these changing relationships, it is difficult to assess whether the compulsory laws influenced marital status based on the graphs alone. To allow the relationship between cohort and marital status to vary before and after the law, an interaction between compulsory law and age at the time of the law is included in all models. By controlling for this change in the cohort-marriage relationship, RD models in this analysis will shed more light on whether and for whom compulsory laws influenced marital status. Future research could investigate how compulsory schooling changed the relationship between cohort and marital status using regression kink design (e.g., Card et al. 2015).

The RD model, shown in Equation 1, predicts marital outcomes (of individual $i$ ) with compulsory assignment, race, and their interaction, while controlling for age up to a quartic (represented by X), state of birth characteristics as a child (indicated by Y), indicators for cohort (in five-year categories, indexed by $j$ ) and state of birth (indexed by $k$ ), the forcing variable (in this case, age at the time of law in one's birth state, called Comp Cohort), and the interaction between the forcing variable and compulsory assignment.

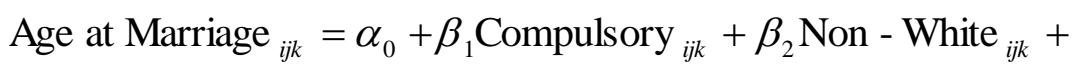

$$
\begin{aligned}
& \beta_{3} \text { Compulsory * Non - White }{ }_{i j k}+\beta_{4} \text { Comp Cohort }_{i j k}+ \\
& \beta_{5} \text { Compulsory * Comp Cohort }{ }_{i j k}+\beta_{6} \mathrm{X}_{i j k}+\beta_{7} \mathrm{Y}_{i j k}+ \\
& \text { Cohort }(5 \mathrm{yrs})_{j}+\text { State }_{k}+\varepsilon_{i j k}
\end{aligned}
$$


With state and cohort fixed effects and continuous age measures, $\beta_{1}$ represents the effect of compulsory assignment on marital outcomes, and $\beta_{3}+\beta_{1}$ is the compulsory effect for nonwhites. Models are run with and without the interaction between compulsory assignment and race to identify both main and interaction effects. Due to concerns about interpreting interactions in logistic regressions and comparing coefficients across samples (Ai and Norton 2003; Mood 2009; Karaca-Mandic et al. 2012), linear probability models are used to predict indicators for married or never married. Results using logistic regression models yield consistent results and are provided in the Appendix. All standard errors are robust to heteroscedasticity and adjusted for state-level clustering.

One caveat in interpreting results of this analysis is that cohorts around the compulsory cutoff in early adopting states are less likely to remain alive in 1910 and 1930 . Therefore, results are less generalizable to the early adopting states (e.g., MA, DC, VT), particularly in 1930. Similarly, cohorts around the compulsory cutoff in late-adopting states are younger and in some cases are not old enough for inclusion in the sample in 1910. In fact, several states passed the compulsory law after 1910 (e.g., MS, GA, AL). Results from 1910 therefore do not generalize to late-adopting states.

A further concern is that, if education increases longevity as Lleras-Muney (2005) found for later extensions of compulsory school age requirements, individuals surviving until 1910 or 1930 could under-represent those who were not required to attend school. In other words, those required to attend school may be more likely to survive and appear in the 1910 and 1930 samples used here. In fact, marriage may be one mechanism through which education increases longevity (e.g., by improving happiness or health [Yap et al. 2012; Gilbert 2005; Murray 2000; Lillard and 
Panis 1996; Waite 1995]). Adults not required to attend school may represent a more select group in 1910 and 1930 than those who were required to attend school. For example, higher SES, white, or healthier individuals may be more likely to survive until 1910 and 1930 and the importance of these factors for survival may be stronger among the non-compulsory group because compulsory schooling may have weakened their importance in the compulsory group. Importantly, the factors that are associated with greater longevity may also be associated with higher likelihood of marriage. Due to these potential differences in survival, results may underestimate the difference between compulsory and non-compulsory groups, leading to attenuation bias in the estimates below.

Beyond attenuation bias, differences in the samples represented could yield different results in 1910 and 1930. For example, if compulsory laws had a greater impact in early-adopting states, results should yield smaller effects in 1930 than in 1910. Alternatively, if compulsory schooling had a greater impact in late-adopting states, perhaps due to increasing importance of education over the $20^{\text {th }}$ century (e.g., Fischer and Hout 2006), results may indicate stronger effects in 1930. Other factors could also yield different results in 1910 and 1930. For example, if education increases age at marriage, examining effects of compulsory schooling on marital status later in the life course could yield more informative estimates. For that reason, results from the 1930 census, when cohorts around the compulsory assignment cutoff were older, could suggest stronger effects of compulsory schooling laws than results from 1910. In terms of differences by race, if racial discrimination declined and education carried more weight (on both the marriage and job markets) over time (Treiman 1970), then compulsory schooling laws may have had stronger effects for non-whites in 1930 than in 1910. For these reasons, we might expect to find greater evidence that compulsory schooling laws increased equality in 1930 than in 1910. 


\section{Results}

Descriptive information for the regression discontinuity sample is presented in Tables 1 and 2. Descriptive statistics for the entire sample are provided in the Appendix (Tables S2 and S3). In both 1910 and 1930, and regardless of whether including the entire or the RD sample, those required to attend school are consistently less likely to be married and more likely to be never married. However, because those required to attend school are in younger cohorts, these marital differences could simply reflect age differences. In contrast, mean age at marriage is similar regardless of compulsory assignment, particularly when excluding those never married in 1930.

[Tables 1 and 2 about here]

Regression analyses, presented in Tables 3 and 4, correct for differences in age, race, cohort, state, and age at time of the compulsory law. Results in Table 3 suggest that non-white women are less likely to be married as adults than white women in 1910. The negative coefficients for non-whites when predicting both married and never married could suggest that non-whites are more likely to be widowed or separated than whites. Few of these estimates reach significance, however, and further research would be required to assess this possibility directly.

[Tables 3 and 4 about here]

Across all models, compulsory assignment has no effect on overall likelihood of being married or age at marriage in 1910. Importantly, however, compulsory assignment has significantly different effects by race among men. The models predicting never married and married in Table 3 show that, compared to white men and non-white men who were not required 
to attend school, non-white men required to attend school are significantly more likely to be single in $1910(\mathrm{p}<0.05)$. Similarly, results of the model predicting likelihood of being married suggest that non-white men are significantly less likely to be married in 1910, but only when required to attend school $(\mathrm{p}<0.05)$. Thus, while the main effects of compulsory assignment do not hold in the RD models, Table 3 suggests that compulsory assignment significantly reduced the likelihood of being married in 1910 for non-white men.

Results for 1930 are shown in Table 4. Similar to 1910 results, the main effect of being required to attend school is not significant (at the $\mathrm{p}<0.05$ level). In nearly all of the 1930 models, however, compulsory assignment has significantly different effects by race. For example, while non-white women are significantly less likely to be married, among those required to attend school that gap is reduced by $25 \%(0.034 /-0.136)$. Compulsory assignment similarly reduced the racial gap in likelihood of being married among men by $40 \%$. Estimates consistently suggest significant racial differences in marital status and timing in 1930. Compulsory schooling laws reduced this racial inequality in marital status, when the mean age of the RD sample was 37 years old.

When predicting age at marriage, results in Table 4 also suggest compulsory assignment had significant equalizing effects by race. Compared to whites, non-whites married at significantly younger ages, ranging from 1.3 to 2.5 years earlier than whites depending on the model. When required to attend school, however, this gap narrows significantly - by $26 \%$ for women and $24 \%$ for men. These results are based on models controlling for never married, but results are similar when excluding those never married. Overall, Table 4 suggests that compulsory schooling significantly reduced the racial gap in marital status and timing in 1930. 
Finally, it is useful to compare results for marital status in 1910 and 1930. In 1910, when the cohorts in the RD sample were younger, compulsory assignment increased the likelihood of being never married and reduced the likelihood of being married for non-white men. By 1930, however, this relationship had reversed; non-white men required to attend school were less likely to be never married and more likely to be married than those not required to attend school. Among women, no significant effects emerged in 1910, but in 1930 non-white women required to attend school were also more likely to be married and to marry at older ages. Thus, among both men and women, the results for 1910 and 1930 are consistent with arguments that education delayed marriage among non-whites.

To summarize results, there are substantial racial differences in marital status and timing. These differences do not generally emerge in 1910 when the cohorts of interest are younger, but there is consistent evidence of racial inequality in 1930, when the cohorts are older. There is no evidence of main effects of the compulsory laws on marital status. However, there is consistent evidence that the compulsory laws had different effects by race, increasing racial equality in marital status and timing in 1930. In fact, depending on the model, results from the RD models suggest that compulsory assignment reduced racial gaps in age at marriage by $24 \%$ for men and $26 \%$ for women. Compulsory schooling laws also reduced racial inequality in the likelihood of being married - by $25 \%$ for women and $40 \%$ for men.

\section{Conclusion}

Research has established an associational relationship between education and marital patterns (Sweeney 2002), but has difficulty isolating the effect of education from other changes that may have contributed to marital change. Capitalizing on state variation in the timing of compulsory schooling laws, this study uses a regression discontinuity approach to estimate 
effects of educational expansion on marital status and timing. Results suggest compulsory laws had important effects on marital patterns, increasing equality in marital status and age at marriage by race. Though the laws required attendance for a relatively short period of time during childhood, results suggest this education held nontrivial effects in adulthood.

Aggregate results suggest no effects of compulsory schooling laws on marriage patterns in the early $20^{\text {th }}$ century. For men, this could reflect the nonlinear relationship between education and marriage found in previous research (Oppenheimer et al. 1997; Oppenheimer and Lewin 1999). If the nonlinear relationship held in the early $20^{\text {th }}$ century, those in the compulsory category could include those with both moderate and high levels of education (relative to others at the time), resulting in null estimates. Alternatively, the results could support the idea that economic factors other than education are more important for marriage patterns among men, at least in the early $20^{\text {th }}$ century.

Although highly educated women in the early $20^{\text {th }}$ century faced a marriage penalty (Cookingham 1984), results of this study suggest that there was no marriage penalty for compulsory schooling. More importantly, although the relationship between education and marriage changed over time for women (Goldstein and Kenney 2001), results suggest the aggregate relationship between compulsory schooling and marriage was similarly null for both men and women.

In terms of race, previous evidence suggests a consistently positive relationship between education and likelihood of marriage among black men (Oppenheimer et al. 1997). Comparing the results for 1910 and 1930 slightly complicates that finding. Rather than a strictly positive relationship, results of this study suggest that compulsory schooling may have reduced the likelihood of early marriage but increased the likelihood of marriage by later adulthood. Thus, 
results suggest that the relationship between education and marriage among black men differs over the life course. This life course variation holds among black women as well.

Marriage is important for individual life experiences, including economic standing (Avellar and Smock 2005; Keister 2004; Hirschl et al. 2003), happiness (Yap et al. 2012; Gilbert 2005), and health (Murray 2000; Lillard and Panis 1996; Waite 1995). Thus, increasing marital equality by race could also reduce racial inequality in those outcomes. Critically, however, racial inequality in marital patterns has implications for child outcomes as well. For example, when parents are married, children are less likely to experience poverty (Morrison and Ritualo 2000) and are healthier in adulthood (Maier and Lachman 2000). By reducing marital inequality by race, therefore, education may reduce inequality in the next generation, weakening the intergenerational transmission process and increasing equality of opportunity. The evidence presented here suggests raising the minimum level of education could significantly reduce racial inequality in the likelihood and timing of marriage, with implications for intergenerational racial inequality.

These results, however, should be considered in light of several limitations. First, data limitations make it difficult to identify the mechanism involved. For example, education could impact the likelihood or timing of marriage through economic potential (Chiappori et al. 2009), self-actualization (Lesthaeghe 2007), altered beliefs or values, raised aspirations, institutionalization of the life course (including refraining from marriage while in school), or facilitation of interactions between potential spouses. This study cannot adjudicate among these mechanisms, but takes steps toward establishing a causal relationship between education and marital patterns. 
Part of the lack of focus on mechanisms stems from a second limitation: education is not included in the 1910 and 1930 censuses. This prevents estimating effects of educational attainment or school attendance on marital patterns. Rather, this study estimates effects of compulsory school attendance laws on marital patterns. This approach has some methodological benefits, such as avoiding issues of heterogeneity in compliance with the law (Freedman 2006). However, results pertain to the relationship between marital patterns and compulsory schooling laws rather than education.

Finally, results are based on data from the early $20^{\text {th }}$ century and may not generalize to the contemporary context. Students in the late 1800s were learning to read, write, and do basic arithmetic. Effects could differ if we extended compulsory schooling at the secondary or postsecondary level. Despite the historical data, however, this study has potential implications for our understanding of demographic patterns. For example, age at first marriage was declining in the first half of the $20^{\text {th }}$ century while educational attainment was rising (Haines 1996; Goldin and Katz 2008). Given all of the economic and demographic changes occurring during this period, including industrialization, urbanization, rising female labor force participation, declining fertility, and rising life expectancy, results suggest that any delaying effects of educational expansion may have been overpowered by other forces encouraging earlier marriage. Thus, while results of this study suggest that education delays marriage among non-whites, null effects among whites in the early $20^{\text {th }}$ century context suggests that education alone is not sufficient to delay marriage among the whole population. Rather, it appears that educational expansion must be accompanied by other changes in order to delay marriage at the societal level.

Education does, however, appear to be a sufficient condition to increase marital equality. Given the central role of marital patterns in contemporary inequality (Wu and Wolfe 2001; 
Ellwood and Jencks 2004; McLanahan 2004), we need to understand not only what drives them but also what policy changes might reduce marital inequality. Existing research emphasizes the importance of economic standing for marital patterns (Sweeney 2002; Goldstein and Kenney 2001; Oppenheimer et al. 1997; Lloyd and South 1996; Goldscheider and Waite 1986), but one aspect of economic standing - education - may be more amenable to policy change than others.

While educational expansion is often justified in economic terms, and research suggests it has important economic benefits (Lutz and Samir 2011; Lutz et al. 2008), the evidence presented here suggests it may have consequences for marital timing and inequality as well. In developing countries, for example, educational expansion could delay marriage and reduce marital inequality. This possibility is supported by research on the relationship between education and age at marriage in Indonesia (Breierova and Duflo 2004) and Turkey (Kirdar et al. 2011).

In the contemporary U.S. context, President Obama urged states in his January 2012 state of the union address to extend the length of compulsory schooling to age 18. Results of this analysis suggest that raising the minimum level of education by extending the compulsory schooling age could delay marriage among those at the bottom of the educational distribution (youth who are likely to drop out of high school) and increase marital equality. Future research should investigate what mechanisms explain the relationship between education and marital patterns and whether expanded compulsory schooling or increasing access to college could increase marital equality in the contemporary U.S. context. While education alone cannot solve inequality, the evidence suggests it could narrow the unequal trajectories or "diverging destinies" (McLanahan 2004) of contemporary children. 


\section{References}

Ai, Chunrong and Edward C. Norton. 2003. "Interaction Terms in Logit and Probit Models." Economics Letters 80(1):123-129.

Avellar, Sarah and Pamela J. Smock. 2005. "The Economic Consequences of the Dissolution of Cohabiting Unions." Journal of Marriage and Family 67(2): 315-327.

Behrens, Angela, Christopher Uggen, and Jeff Manza. (2003). Ballot Manipulation and the 'Menace of Negro Domination': Racial Threat and Felon Disenfranchisement in the United States, 1850-2002. American Journal of Sociology, 109, 559-605.

Bennett, Neil G., David E. Bloom, and Patricia H. Craig. 1989. "The Divergence of Black and White Marriage Patterns." American Journal of Sociology 95(3): 692-722.

Blossfeld, Hans-Peter and Johannes Huinink. 1991. "Human Capital Investments or Norms of Role Transition? How Women's Schooling and Career Affect the Process of Family Formation." American Journal of Sociology 97(1): 143-168.

Breierova, Lucia and Esther Duflo. 2004. "The Impact of Education on Fertility and Child Mortality: Do Fathers Really Matter Less than Mothers?” NBER Working Paper 10513. Retrieved April 29, 2016 from http://www.nber.org/papers/w10513.

Card, David, David S. Lee, Zhuan Pei, and Andrea Weber. 2015. "Inference on Causal Effects in a Generalized Regression Kink Design.” Econometrica 83(6): 2453-83.

Chiappori, Pierre-Andre, Murat Iyigun, and Yoram Weiss. 2009. "Investment in Schooling and the Marriage Market." The American Economic Review 99(5): 1689-1713.

Commissioner of Education. 1891. Report of the Commissioner of Education for the Year 18889, 1: 470-531. Washington, DC: Government Printing Office.

Cookingham, Mary E. 1984. "Bluestockings, Spinsters, and Pedagogues: Women College Graduates, 1865 to 1910." Population Studies 38: 349-364.

Cooney, Teresa M. and Dennis P. Hogan. 1991. "Marriage in an Institutionalized Life Course: First Marriage among American Men in the Twentieth Century." Journal of Marriage and Family 53(1): 178-190.

Elliott, Diana B., Kristy Krivickas, Matthew W. Brault, and Rose M. Kreider. 2012. "Historical Marriage Trends from 1890-2010: A Focus on Race Differences.” SEHSD Working Paper Number 2012-12. Retrieved April 27, 2016 from https://www.census.gov/hhes/socdemo/marriage/data/.../ElliottetalPAA2012paper.pdf.

Ellwood, David T. and Christopher Jencks. 2004. "The Uneven Spread of Single-Parent Families: What Do We Know? Where Do We Look for Answers?” Pp. 3-78 in Social Inequality, edited by K. M. Neckerman. New York: Russell Sage Foundation.

Fischer, Claude S. and Michael Hout. 2006. Century of Difference: How America Changed in the Last One Hundred Years. New York: Russell Sage Foundation.

Freedman, David A. 2006. "Statistical Models for Causation: What Inferential Leverage Do They Provide?" Evaluation Review 30(6): 691-713.

Freeman J.B., A.M. Penner, A. Saperstein, M. Scheutz, and N. Ambady. 2011. "Looking the Part: Social Status Cues Shape Race Perception.” PLoS ONE 6(9):e25107.

Gilbert, Daniel T. 2005. Stumbling on Happiness. New York: Random House.

Goldin, Claudia. 1990. Understanding the Gender Gap: An Economic History of American Women. New York: Oxford University Press.

Goldin, Claudia and Lawrence F. Katz. 2008. The Race between Education and Technology. Cambridge: Harvard University Press. 
Goldin, Claudia and Lawrence F. Katz. 2011. "Mass Secondary Schooling and the State: The Role of State Compulsion in the High School Movement.” In D. Costa and N. Lamoreaux, Understanding Long Run Economic Growth. Cambridge: Cambridge University Press.

Goldscheider, Frances Kobrin and Linda J. Waite. 1986. "Sex Differences in the Entry into Marriage.” American Journal of Sociology 92(1): 91-109.

Goldstein, Joshua R. and Catherine T. Kenney. 2001. "Marriage Delayed or Marriage Forgone? New Cohort Forecasts of First Marriage for U.S. Women." American Sociological Review 66: 506-519.

Greenwood, Jeremy, Nezih Guner, Georgi Kocharkov, and Czar Santos. 2014. "Marry Your Like: Assortative Mating and Income Inequality." NBER Working Paper 19829. Retrieved April 16, 2014 from www.nber.org/papers/w19829.

Haines, Michael R. 1996. "Long-Term Marriage Patterns in the United States from Colonial Times to the Present." The History of the Family 1(1): 15-39.

Harknett, Kristen and Arielle Kuperberg. 2011. "Education, Labor Markets and the Retreat from Marriage." Social Forces 90(1): 41-64.

Hirschl, Thomas A., Joyce Altobelli, and Mark R. Rank. 2003. "Does Marriage Increase the Odds of Affluence? Exploring the Life Course Probabilities." Journal of Marriage and Family 65(4): 927-938.

ICPSR (Inter-university Consortium for Political and Social Research). (1970). Historical, Demographic, Economic, and Social Data: The United States, 1790-1970 [Computer file]. Ann Arbor, MI: ICPSR.

Imbens, Guido W. and Thomas Lemieux. 2008. "Regression Discontinuity Designs: A Guide to Practice." Journal of Econometrics 142: 615-635.

Isen, Adam and Betsey Stevenson. 2010. "Women's Education and Family Behavior: Trends in Marriage, Divorce and Fertility.” NBER Working Paper 15725. Retrieved April 15, 2014 from www.nber.org/papers/w15725.

Karaca-Mandic, Pinar, Edward C. Norton, and Bryan Dowd. 2012. "Interaction Terms in NonLinear Models." Health Services Research 47(1 Pt 1):255-74.

Keister, Lisa A. 2004. "Race, Family Structure, and Wealth: The Effect of Childhood Family on Adult Asset Ownership." Sociological Perspectives 47(2): 161-187.

Kena, Grace, Lauren Musu-Gillette, Jennifer Robinson, Xiaolei Wang, Amy Rathbun, Jijun Zhang, Sidney Wilkinson-Flicker, Amy Barmer, and Erin Dunlop Velez. 2015. The Condition of Education 2015 (NCES 2015-144). U.S. Department of Education, National Center for Education Statistics. Washington, DC. Retrieved April 26, 2016 from http://nces.ed.gov/pubsearch.

Kirdar, Murat G., Meltem Dayioglu Tayfur, and Ismet Koc. 2011. "The Effects of Compulsory Schooling Laws on Teenage Marriage and Births in Turkey." IZA Discussion Paper No. 5887. Retrieved April 29, 2016 from http://ftp.iza.org/dp5887.pdf.

Landes, William M. and Lewis C. Solmon. 1972. Compulsory Schooling Legislation: An Economic Analysis of Law and Social Change in the Nineteenth Century. The Journal of Economic History, 32(1), 54-91.

Lee, David S. and Thomas Lemieux. 2010. "Regression Discontinuity Designs in Economics." Journal of Economic Literature 48: 281-355.

Lee, David S. and David Card. 2008. "Regression Discontinuity Inference with Specification Error." Journal of Econometrics 142: 655-674.

Lesthaeghe, Ron J. 2007. "The Second Demographic Transition.” The Blackwell Encyclopedia of Sociology. Hoboken, NJ: Wiley-Blackwell. 
Lillard, Lee A. and Constantijn W.A. Panis. 1996. "Marital Status and Mortality: The Role of Health.” Demography 33(3): 313-327.

Lleras-Muney, Adriana. 2005. The Relationship between Education and Adult Mortality in the United States. Review of Economic Studies, 72, 189-221.

Lloyd, Kim M. and Scott J. South. 1996. “Contextual Influences on Young Men's Transition to First Marriage.” Social Forces 74(3): 1097-1119.

Looney, Adam and Michael Greenstone. 2012. "The Marriage Gap: The Impact of Economic and Technological Change on Marriage Rates." The Hamilton Project. Washington, DC: The Brookings Institute. Retrieved April 16, 2014 from www.hamiltonproject.org/files/downloads_and_links/020312_jobs_greenstone looney.pdf.

Lutz, Wolfgang and Samir K.C. 2011. "Global Human Capital: Integrating Education and Population.” Science 333: 587-592.

Lutz, Wolfgang, Jesus Crespo Cuaresma, and Warren Sanderson. 2008. "The Demography of Educational Attainment and Economic Growth.” Science 319: 1047-1048.

Maier, E. Hailey and Margie E. Lachman. 2000. "Consequences of Early Parental Loss and Separation for Health and Well-Being in Midlife." International Journal of Behavioral Development 24(2): 183-89.

McLanahan, Sara. 2004. "Diverging Destinies: How Children Are Faring Under the Second Demographic Transition.” Demography 41(4): 607-627.

McCrary, Justin. 2008. "Manipulation of the Running Variable in the Regression Discontinuity Design: A Density Test.” Journal of Econometrics 142(2): 698-714.

Molloy, Raven, Christopher L. Smith, and Abigail Wozniak. 2011. "Internal Migration in the United States." Finance and Economics Discussion Series. Washington, DC: Federal Reserve Board. Retrieved from www.federalreserve.gov/pubs/feds/2011/201130/201130pap.pdf.

Mood, Carina. 2010. "Logistic Regression: Why We Cannot Do What We Think We Can Do, and What We Can Do About It." European Sociological Review 26(1):67-82.

Moore, Ernest Carroll. 1902. "The Effect of Compulsory Education Upon the Poor." Western Journal of Education, 7(6): 339-345.

Morrison, Donna Ruane and Amy Ritualo. 2000. “Routes to Children's Economic Recovery After Divorce: Are Cohabitation and Remarriage Equivalent?" American Sociological Review 65(4): 560-580.

Murray, John E. 2000. "Marital Protection and Marital Selection: Evidence from a HistoricalProspective Sample of American Men.” Demography 37(4): 511-521.

National Center for Health Statistics. 2014. Health, United States, 2014: With Special Feature on Adults Aged 55-64. Hyattsville, MD: U.S. Government Printing Office.

Oppenheimer, Valerie Kincade and Alisa Lewin. 1999. "Career Development and Marriage Formation in a Period of Rising Inequality: Who Is at Risk? What Are Their Prospects?" Pp. 189-225 in Transitions to Adulthood in a Changing Economy: No Work, No Family, No Future?, edited by A. Booth, A.C. Crouter, and M.J. Shanahan. Westport, CT: Praeger. Oppenheimer, Valerie Kincade, Matthijs Kalmijn, and Nelson Lim. 1997. "Men's Career Development and Marriage Timing During a Period of Rising Inequality." Demography 34(3): 311-330.

Oreopoulos, Philip. 2009. "Would More Compulsory Schooling Help Disadvantaged Youth? Evidence from Recent Changes to School-Leaving Laws." An Economic Perspective on the Problems of Disadvantaged Youth, J. Gruber (ed.) pp. 85-112. Chicago: University of Chicago Press. 
Preston, Samuel H. and Alan Thomas Richards. 1975. "The Influence of Women's Work Opportunities on Marriage Rates.” Demography 12(2): 209-222.

Puerta, Juan Manuel. 2009. 'The Fewer, the Merrier': Compulsory Schooling Laws, Human Capital, and Fertility in the United States. Paper presented at Population Association of America Annual Meeting April 17, 2010. Dallas, TX. http://paa2010.princeton.edu/download.aspx?submissionId=102057.

Rauscher, Emily. 2014. "Hidden Gains: Effects of Early U.S. Compulsory Schooling Laws on Attendance and Attainment by Social Background." Educational Evaluation and Policy Analysis 36(4): 501-518.

Steven Ruggles, Katie Genadek, Ronald Goeken, Josiah Grover, and Matthew Sobek. 2015. Integrated Public Use Microdata Series: Version 6.0 [dataset]. Minneapolis: University of Minnesota.

Saperstein, Aliya and Aaron Gullickson. 2013. "A Mulatto Escape Hatch? Examining Evidence of U.S. Racial and Social Mobility in the Jim Crow Era.” Demography 50(5): 1921-42.

Saperstein, Aliya and Andrew M. Penner. 2012. "Racial Fluidity and Inequality in the United States." American Journal of Sociology 118(3): 676-727.

Steinhilber, August W. and Carl J. Sokolowski. 1966. State Law on Compulsory Attendance. U.S. Department of Health, Education, and Welfare, Office of Education, Circular 793. Washington: General Printing Office.

Sweeney, Megan M. 2002. "Two Decades of Family Change: The Shifting Economic Foundations of Marriage." American Sociological Review 67: 132-147.

Thompson, Derek. 2013. "How America's Marriage Crisis Makes Income Inequality So Much Worse." The Atlantic, October 1. Retrieved April 16, 2014 from www.theatlantic.com/ business/archive/2013/10/how-americas-marriage-crisis-makes-income-inequality-so-muchworse/280056/.

Treiman, Donald J. 1970. "Industrialization and Social Stratification." In Social Stratification: Research and Theory for the 1970s. Edward O. Laumann (ed.). New York: The BobbsMerrill Company: 207-234.

U.S. Bureau of Education. (1914). Monthly Record of Current Educational Publications. Bulletin 572 , no. 1.

U.S. Bureau of the Census. (1924). School Attendance in 1920: An Analysis of School Attendance in the United States and in the Several States, with a Discussion of the Factors Involved. In Census Monographs V, by Frank Alexander Ross. Washington, DC: Government Printing Office. www2.census.gov/prod2/decennial/documents/ 04097225no5 TOC.pdf U.S. Census Bureau. (1975). Historical Statistics of the United States: Colonial Times to 1970. Washington: General Printing Office.

Waite, Linda J. 1995. “Does Marriage Matter?” Demography 32(4): 483-507.

Waite, Linda J. and Glenna D. Spitze. 1981. "Young Women's Transition to Marriage." Demography 18(4): 681-694.

Wu, Lawrence L., and Barbara Wolfe (Eds.). 2001. Out of Wedlock: Causes and Consequences of Nonmarital Fertility. New York: Russell Sage Foundation.

Yap, Stevie C.Y., Ivana Anusic, and Richard E. Lucas. 2012. "Does Personality Moderate Reaction and Adaptation to Major Life Events? Evidence from the British Household Panel Survey." Journal of Research in Personality 46(5): 477-488. 
Tables and Figures

Table 1: Descriptive Statistics 5-Year Regression Discontinuity Sample - 1910

\begin{tabular}{|c|c|c|c|c|}
\hline & All & Std Dev & Non-Compulsory & Compulsory \\
\hline \multicolumn{5}{|l|}{ Women } \\
\hline Married & 0.55 & 0.50 & 0.57 & 0.53 \\
\hline Age at Current Marriage (excl remarried) $\dagger$ & 21.40 & 4.90 & 21.20 & 21.62 \\
\hline Remarried $+\dot{t}$ & 0.07 & 0.25 & 0.07 & 0.07 \\
\hline Never Married & 0.36 & 0.48 & 0.34 & 0.39 \\
\hline Non-White & 0.09 & 0.28 & 0.11 & 0.06 \\
\hline Age & 31.23 & 12.70 & 31.76 & 30.66 \\
\hline Compulsory School & 0.48 & 0.50 & 0.00 & 1.00 \\
\hline Compulsory Cohort (centered) & -0.37 & 2.80 & 1.95 & -2.91 \\
\hline Cohort (5-yr intervals) & 1880.66 & 12.72 & 1880.19 & 1881.18 \\
\hline \multicolumn{5}{|l|}{ State of Birth Chars (@ age 10) } \\
\hline$\%$ Employed in Manufacturing & 0.06 & 0.04 & 0.06 & 0.07 \\
\hline$\%$ Non-White Prisoners & 0.24 & 0.22 & 0.28 & 0.20 \\
\hline Incarceration Rate (per 100k) & 86.21 & 35.65 & 85.16 & 87.35 \\
\hline$\%$ Illiterate & 0.11 & 0.08 & 0.13 & 0.09 \\
\hline$\%$ Foreign & 0.12 & 0.09 & 0.11 & 0.13 \\
\hline $\mathrm{N}$ & 39,499 & & 20,594 & 18,905 \\
\hline $\mathrm{N}^{\dagger}$ & 20,327 & & 10,896 & 9,431 \\
\hline $\mathrm{N}$ & 21,833 & & 11,712 & 10,121 \\
\hline \multicolumn{5}{|l|}{ Men } \\
\hline Married & 0.48 & 0.50 & 0.49 & 0.46 \\
\hline Age at Current Marriage (excl remarried) $\dagger$ & 25.21 & 5.37 & 25.13 & 25.31 \\
\hline Remarried $\grave{\ddagger}$ & 0.08 & 0.27 & 0.08 & 0.08 \\
\hline Never Married & 0.47 & 0.50 & 0.46 & 0.49 \\
\hline Non-White & 0.08 & 0.27 & 0.10 & 0.05 \\
\hline Age & 31.68 & 12.71 & 32.30 & 31.00 \\
\hline Compulsory School & 0.48 & 0.50 & 0.00 & 1.00 \\
\hline Compulsory Cohort (centered) & -0.37 & 2.81 & 1.96 & -2.90 \\
\hline Cohort (5-yr intervals) & 1880.22 & 12.73 & 1879.63 & 1880.85 \\
\hline \multicolumn{5}{|l|}{ State of Birth Chars (@ age 10) } \\
\hline \% Employed in Manufacturing & 0.06 & 0.04 & 0.06 & 0.07 \\
\hline$\%$ Non-White Prisoners & 0.24 & 0.21 & 0.28 & 0.19 \\
\hline Incarceration Rate (per 100k) & 86.05 & 36.01 & 85.05 & 87.14 \\
\hline$\%$ Illiterate & 0.11 & 0.08 & 0.13 & 0.09 \\
\hline$\%$ Foreign & 0.13 & 0.09 & 0.12 & 0.14 \\
\hline $\mathrm{N}$ & 39,915 & & 20,795 & 19,120 \\
\hline $\mathrm{N}^{\dagger}$ & 17,545 & & 9,326 & 8,219 \\
\hline $\mathrm{N}$ & 19,095 & & 10,190 & 8,905 \\
\hline
\end{tabular}

Source: 1910 Census, limited to those within 5 years of compulsory school cutoff. Married includes those with spouse present. Age at current marriage includes those married with spouse present or absent, but excludes those 
who are remarried. For those who are married (spouse present or absent), remarried indicates whether the current marriage is a remarriage.

Table 2: Descriptive Statistics 5-Year Regression Discontinuity Sample - 1930

\begin{tabular}{|c|c|c|c|c|}
\hline & All & Std Dev & Non-Compulsory & Compulsory \\
\hline \multicolumn{5}{|l|}{ Women } \\
\hline Married & 0.70 & 0.46 & 0.69 & 0.70 \\
\hline Age at 1st Marriage & 15.69 & 10.81 & 15.76 & 15.63 \\
\hline Age at 1 st Marriage (excl never married) $\dagger$ & 17.66 & 9.84 & 17.45 & 17.85 \\
\hline Never Married & 0.11 & 0.31 & 0.10 & 0.12 \\
\hline Non-White & 0.16 & 0.37 & 0.16 & 0.16 \\
\hline Age & 43.28 & 13.69 & 45.64 & 41.27 \\
\hline Compulsory School & 0.54 & 0.50 & 0.00 & 1.00 \\
\hline Compulsory Cohort (centered) & -0.77 & 2.85 & 1.92 & -3.05 \\
\hline Cohort (5-year intervals) & 1888.67 & 13.78 & 1886.30 & 1890.67 \\
\hline \multicolumn{5}{|l|}{ State of Birth Chars (@ age 10) } \\
\hline$\%$ Employed in Manufacturing & 0.05 & 0.03 & 0.05 & 0.06 \\
\hline$\%$ Non-White Prisoners & 0.34 & 0.24 & 0.35 & 0.32 \\
\hline Incarceration Rate (per 100k) & 85.12 & 33.24 & 86.44 & 84.00 \\
\hline$\%$ Illiterate & 0.13 & 0.08 & 0.14 & 0.12 \\
\hline$\%$ Foreign & 0.09 & 0.08 & 0.09 & 0.10 \\
\hline $\mathrm{N}$ & 43,141 & & 19,809 & 23,332 \\
\hline $\mathrm{N} \dagger$ & 38,334 & & 17,895 & 20,439 \\
\hline \multicolumn{5}{|l|}{ Men } \\
\hline Married & 0.74 & 0.44 & 0.75 & 0.73 \\
\hline Age at 1 st Marriage & 19.15 & 11.83 & 19.71 & 18.69 \\
\hline Age at 1 st Marriage (excl never married) $\dagger$ & 22.61 & 9.33 & 22.61 & 22.60 \\
\hline Never Married & 0.15 & 0.36 & 0.13 & 0.17 \\
\hline Non-White & 0.15 & 0.36 & 0.16 & 0.15 \\
\hline Age & 43.45 & 13.52 & 45.63 & 41.61 \\
\hline Compulsory School & 0.54 & 0.50 & 0.00 & 1.00 \\
\hline Compulsory Cohort (centered) & -0.78 & 2.85 & 1.92 & -3.05 \\
\hline Cohort (5-year intervals) & 1888.49 & 13.60 & 1886.30 & 1890.35 \\
\hline \multicolumn{5}{|l|}{ State of Birth Chars (@ age 10) } \\
\hline$\%$ Employed in Manufacturing & 0.05 & 0.03 & 0.05 & 0.06 \\
\hline$\%$ Non-White Prisoners & 0.33 & 0.23 & 0.35 & 0.32 \\
\hline Incarceration Rate (per 100k) & 85.28 & 33.60 & 86.48 & 84.26 \\
\hline$\%$ Illiterate & 0.13 & 0.08 & 0.14 & 0.11 \\
\hline$\%$ Foreign & 0.09 & 0.08 & 0.09 & 0.10 \\
\hline $\mathrm{N}$ & 42,732 & & 19,581 & 23,151 \\
\hline $\mathrm{N} \dagger$ & 36,194 & & 17,066 & 19,128 \\
\hline
\end{tabular}

Source: 1930 Census, limited to those within 5 years of compulsory school cutoff. Marriage is limited to those married with spouse present. Age at first marriage includes those with spouse present or absent and excludes those never married. 
Table 3: Coefficients from Regression Discontinuity Models Predicting Marital Status in 1910

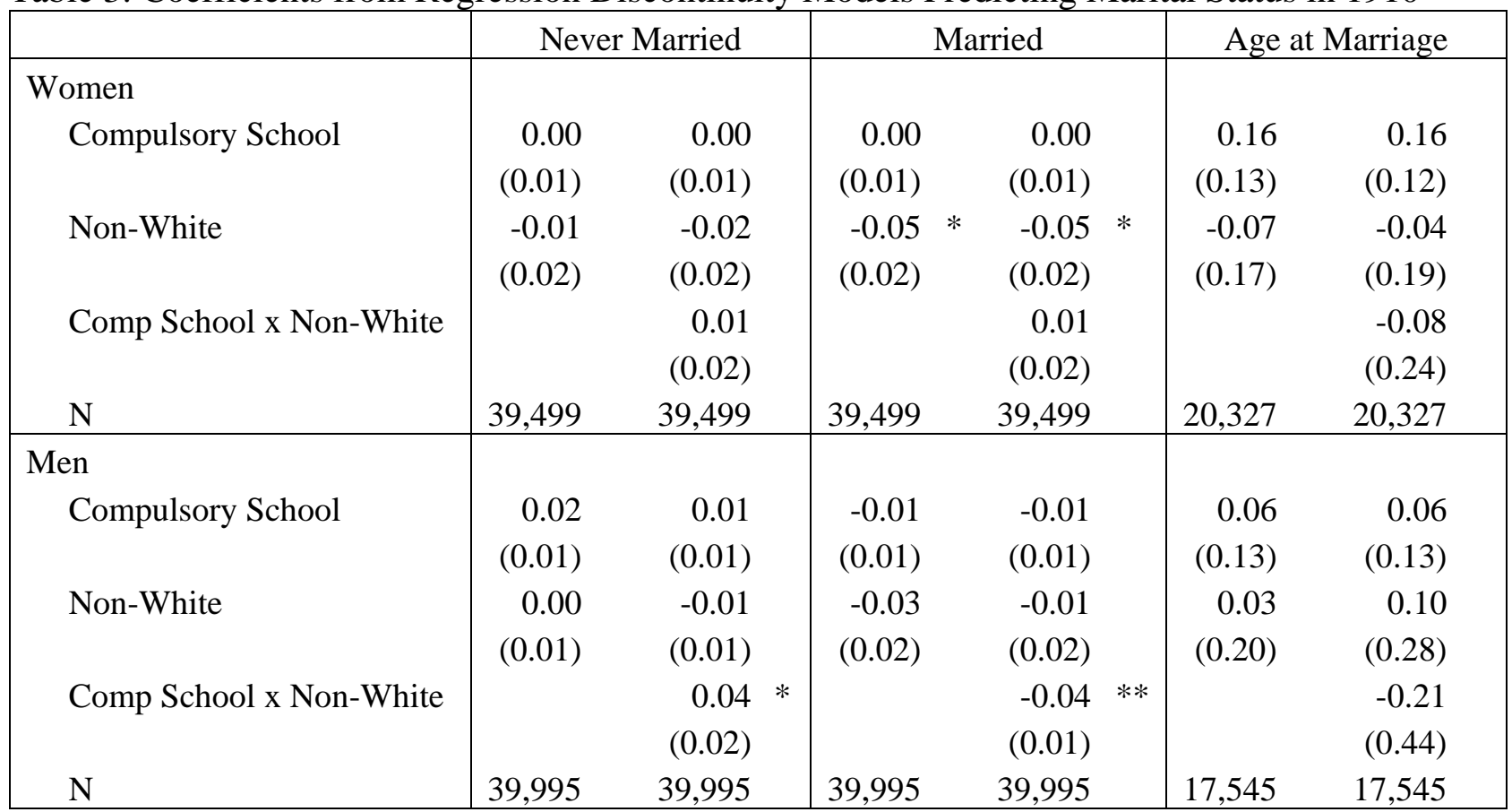

Source: 1910 Census. * $\mathrm{p}<0.05 ;+\mathrm{p}<0.10$ Robust standard errors adjusted for state-level clustering are in parentheses.

Sample is limited to those five years on each side of the compulsory assignment cutoff. Models include controls for age at time of the law (the assignment variable) and its interaction with compulsory assignment, age up to a quartic, cohort (in five year intervals), state of birth, and state characteristics that best explain state variation in timing of compulsory attendance laws (\% manufacturing employment, $\%$ non-white prisoners, incarceration rate, $\%$ illiterate, $\%$ foreign). Models predicting age at marriage exclude remarried. Coefficients for married and never married are from linear probability models. Results using logit models to predict binary outcomes are provided in the Appendix. 
Table 4: Coefficients from Regression Discontinuity Models Predicting Marital Status in 1930

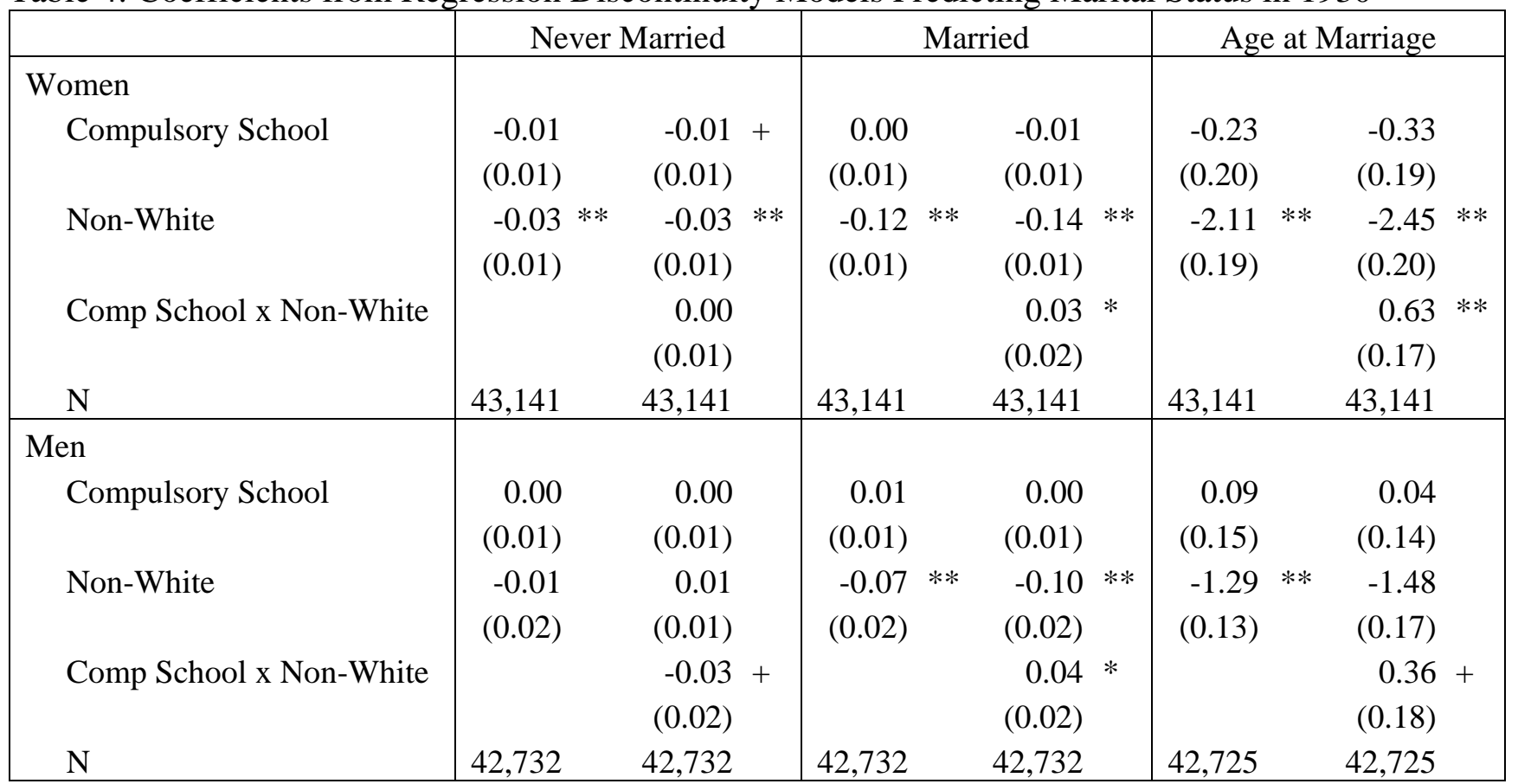

Source: 1930 Census. * $\mathrm{p}<0.05 ;+\mathrm{p}<0.10$ Robust standard errors adjusted for state-level clustering are in parentheses.

Sample is limited to those five years on each side of the compulsory assignment cutoff. Models include controls for age at time of the law (the assignment variable) and its interaction with compulsory assignment, age up to a quartic, cohort (in five year intervals), state of birth, and state characteristics that best explain state variation in timing of compulsory attendance laws (\% manufacturing employment, $\%$ non-white prisoners, incarceration rate, $\%$ illiterate, $\%$ foreign). Models predicting age at marriage also control for never married. Coefficients for married and never married are from linear probability models. Results using logit models to predict binary outcomes are provided in the Appendix. 
Figure 1: Marital Status by Race and Age at Time of the Compulsory Law - 1910 Panel A: Proportion Married

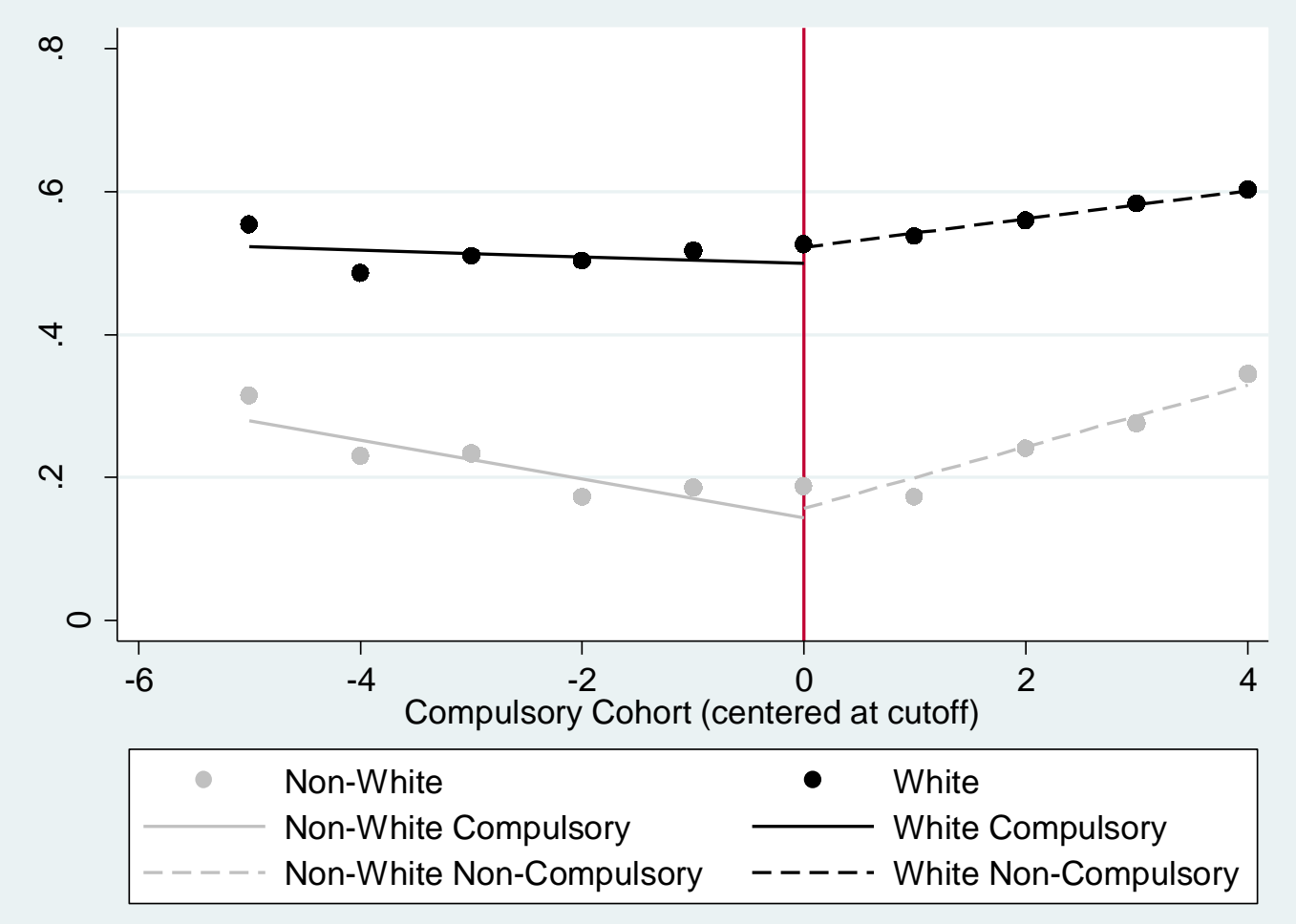

Panel B: Proportion Never Married

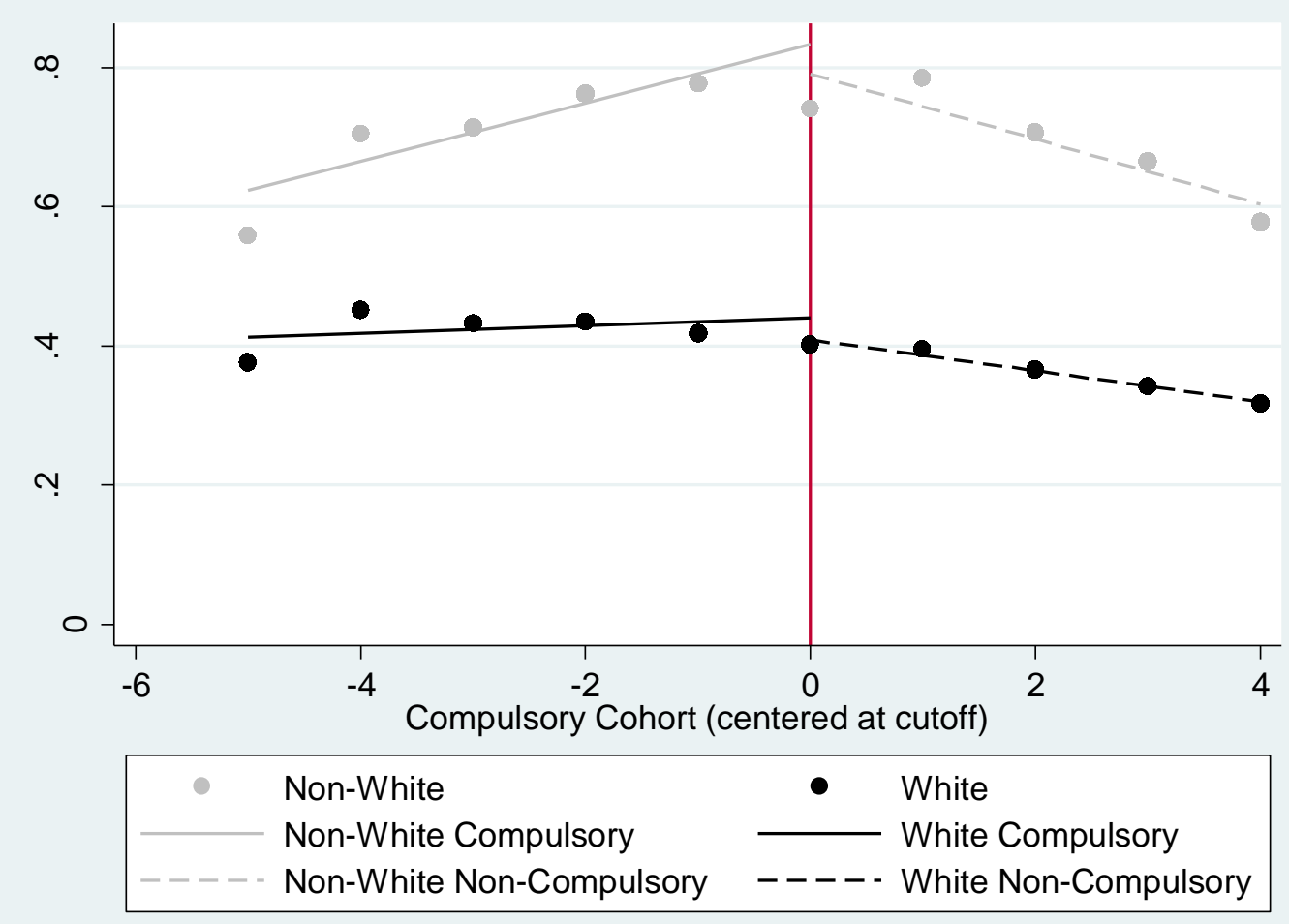


Figure 2: Marital Status by Race and Age at Time of the Compulsory Law - 1930 Panel A: Proportion Married

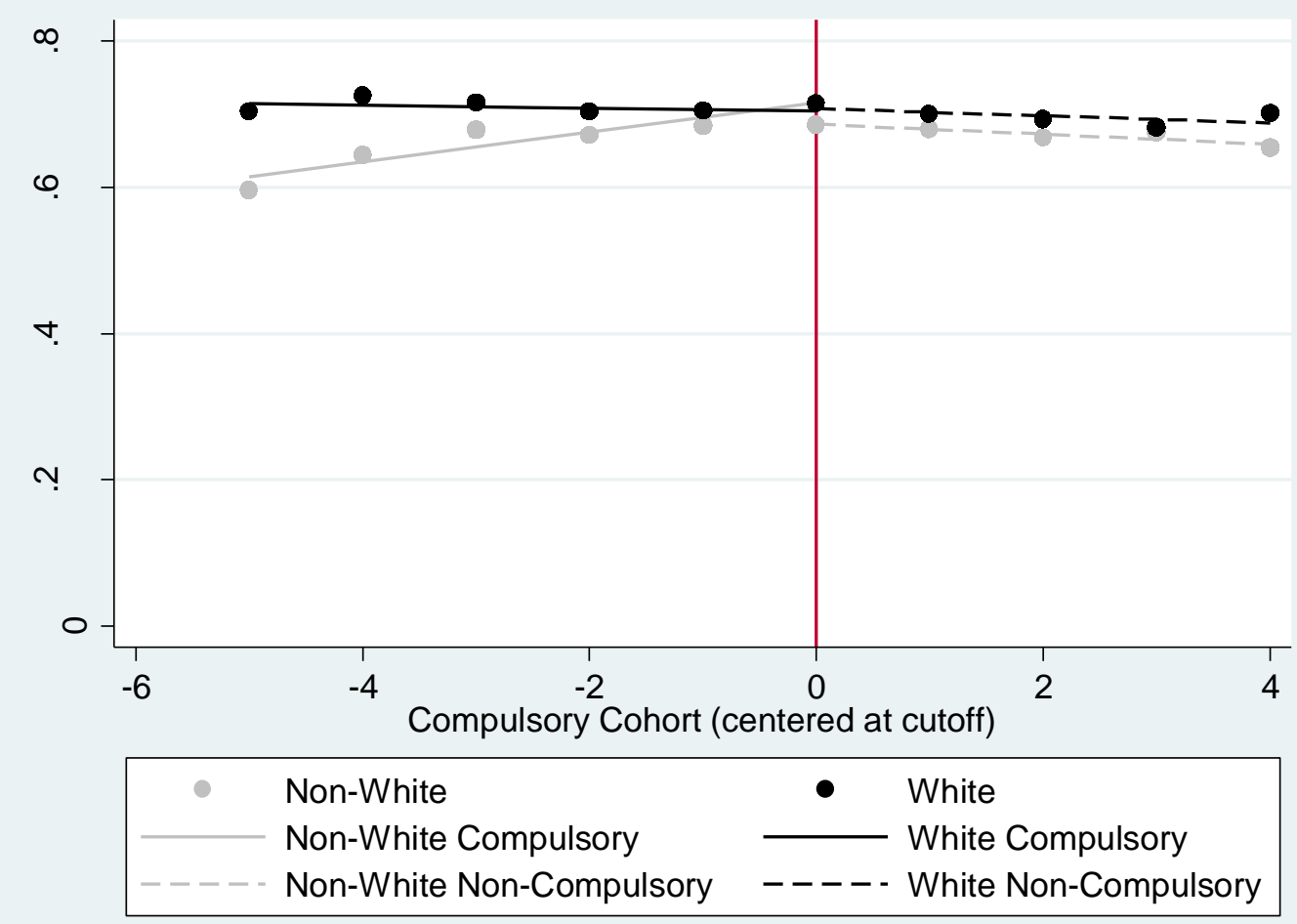

Panel B: Proportion Never Married

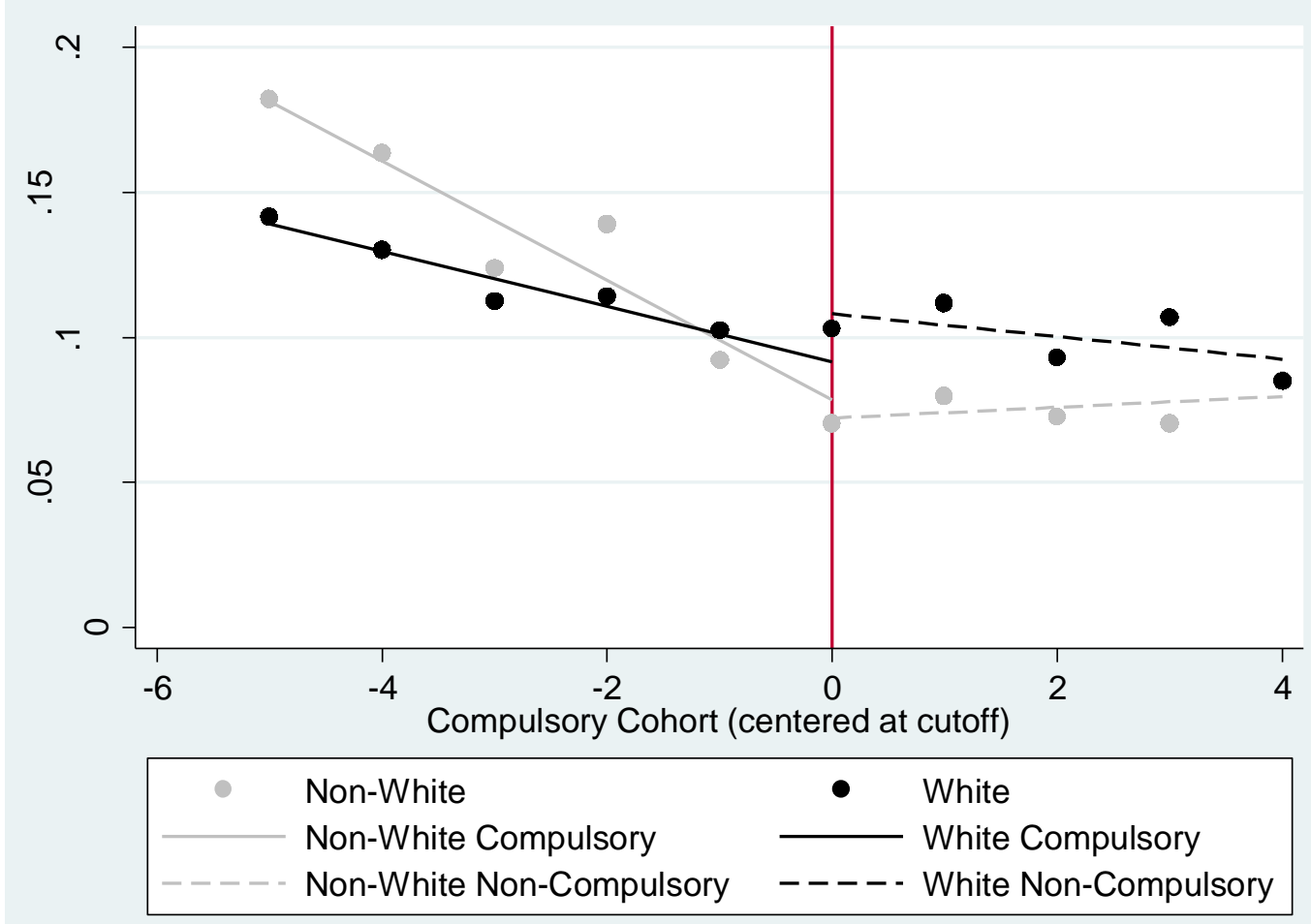




\section{Appendix}

Table S1: Year of First Compulsory School Attendance Law by State

\begin{tabular}{|l|c|}
\hline State & $\begin{array}{c}\text { Compulsory } \\
\text { School Year }\end{array}$ \\
\hline Massachusetts & 1852 \\
District of Columbia & 1864 \\
Vermont & 1867 \\
Michigan, New Hampshire, Washington & 1871 \\
Connecticut, New Mexico & 1872 \\
Nevada & 1873 \\
California, Kansas, New York & 1874 \\
Maine, New Jersey & 1875 \\
Wyoming & 1876 \\
Ohio & 1877 \\
Wisconsin & 1879 \\
Illinois, Montana, N./S. Dakota, Rhode Island & 1883 \\
Minnesota & 1885 \\
Nebraska, Idaho & 1887 \\
Colorado, Oregon & 1889 \\
Utah & 1890 \\
Pennsylvania & 1895 \\
Hawaii, Kentucky & 1896 \\
Indiana, West Virginia & 1897 \\
Arizona & 1899 \\
Iowa, Maryland & 1902 \\
Missouri, Tennessee & 1905 \\
Delaware, North Carolina, Oklahoma & 1907 \\
Virginia & 1908 \\
Arkansas & 1909 \\
Louisiana & 1910 \\
Alabama, Florida, South Carolina, Texas & 1915 \\
Georgia & 1916 \\
Mississippi & 1929 \\
Alaska & 18 \\
\hline
\end{tabular}

Source: U.S. Bureau of Education 1914: 10; U.S. Bureau of the Census 1924: 22; Steinhilber and Sokolowski 1966. 
Table S2: Descriptive Statistics - Full Sample 1910

\begin{tabular}{|c|c|c|c|c|}
\hline & All & Std Dev & Non-Compulsory & Compulsory \\
\hline \multicolumn{5}{|l|}{ Women } \\
\hline Married & 0.55 & 0.50 & 0.63 & 0.45 \\
\hline Age at Current Marriage (excl remarr) $\dagger$ & 21.66 & 5.23 & 21.80 & 21.44 \\
\hline Remarried $t$ & 0.08 & 0.27 & 0.10 & 0.05 \\
\hline Never Married & 0.32 & 0.47 & 0.18 & 0.49 \\
\hline Non-White & 0.12 & 0.33 & 0.20 & 0.02 \\
\hline Age & 35.09 & 35.09 & 41.87 & 26.73 \\
\hline Compulsory School & 0.45 & 0.50 & 0.00 & 1.00 \\
\hline Compulsory Cohort (centered) & 2.60 & 22.64 & 19.01 & -17.62 \\
\hline Cohort (5-yr intervals) & 1876.79 & 15.67 & 1870.04 & 1885.10 \\
\hline \multicolumn{5}{|l|}{ State of Birth Chars (at age 10) } \\
\hline$\%$ Employed in Manufacturing & 0.06 & 0.05 & 0.04 & 0.09 \\
\hline$\%$ Non-White Prisoners & 0.28 & 0.27 & 0.40 & 0.13 \\
\hline Incarceration Rate (per 100k) & 91.57 & 51.59 & 88.43 & 95.45 \\
\hline$\%$ Illiterate & 0.15 & 0.14 & 0.21 & 0.07 \\
\hline$\%$ Foreign & 0.13 & 0.10 & 0.08 & 0.19 \\
\hline $\mathrm{N}$ & 237,392 & & 131,059 & 106,333 \\
\hline $\mathrm{N}+$ & 119,525 & & 73,385 & 46,140 \\
\hline $\mathrm{N} t$ & 130,911 & & 82,169 & 48,742 \\
\hline \multicolumn{5}{|l|}{ Men } \\
\hline Married & 0.53 & 0.50 & 0.66 & 0.36 \\
\hline Age at Current Marriage (excl remarr) $\dagger$ & 25.46 & 5.68 & 25.79 & 24.78 \\
\hline Remarried $t$ & 0.12 & 0.32 & 0.15 & 0.05 \\
\hline Never Married & 0.40 & 0.49 & 0.24 & 0.61 \\
\hline Non-White & 0.12 & 0.32 & 0.19 & 0.02 \\
\hline Age & 35.40 & 15.51 & 42.18 & 26.87 \\
\hline Compulsory School & 0.44 & 0.50 & 0.00 & 1.00 \\
\hline Compulsory Cohort (centered) & 3.05 & 22.59 & 19.28 & -17.37 \\
\hline Cohort (5-yr intervals) & 1876.49 & 15.52 & 1869.74 & 1884.99 \\
\hline \multicolumn{5}{|l|}{ State of Birth Chars (at age 10) } \\
\hline$\%$ Employed in Manufacturing & 0.06 & 0.05 & 0.04 & 0.09 \\
\hline$\%$ Non-White Prisoners & 0.28 & 0.27 & 0.39 & 0.13 \\
\hline Incarceration Rate (per 100k) & 91.42 & 51.61 & 88.22 & 95.44 \\
\hline$\%$ Illiterate & 0.15 & 0.14 & 0.21 & 0.07 \\
\hline$\%$ Foreign & 0.13 & 0.10 & 0.08 & 0.19 \\
\hline $\mathrm{N}$ & 241,577 & & 134,564 & 107,013 \\
\hline $\mathrm{N}^{+}$ & 112,546 & & 75,654 & 36,892 \\
\hline $\mathrm{N} t$ & 127,831 & & 88,788 & 39,043 \\
\hline
\end{tabular}

Source: 1910 Census. Marriage is limited to those married with spouse present. Age at current marriage includes those married with spouse present or absent, but excludes those who are remarried. For those who are married (spouse present or absent), remarried indicates whether the current marriage is a remarriage. 
Table S3: Descriptive Statistics - Full Sample 1930

\begin{tabular}{|c|c|c|c|c|}
\hline & All & Std Dev & Non-Compulsory & Compulsory \\
\hline \multicolumn{5}{|l|}{ Women } \\
\hline Married & 0.57 & 0.50 & 0.60 & 0.56 \\
\hline Age at 1 st Marriage (excl never married) $\dagger$ & 17.84 & 9.48 & 15.07 & 19.12 \\
\hline Never Married & 0.29 & 0.45 & 0.08 & 0.36 \\
\hline Non-White & 0.10 & 0.30 & 0.18 & 0.07 \\
\hline Age & 36.70 & 16.32 & 54.26 & 31.03 \\
\hline Compulsory School & 0.76 & 0.43 & 0.00 & 1.00 \\
\hline Compulsory Cohort (centered) & -16.39 & 23.22 & 14.23 & -26.29 \\
\hline Cohort (5-yr intervals) & 1895.20 & 16.32 & 1877.67 & 1900.86 \\
\hline \multicolumn{5}{|l|}{ State of Birth Chars (at age 10) } \\
\hline$\%$ Employed in Manufacturing & 0.07 & 0.05 & 0.04 & 0.08 \\
\hline$\%$ Non-White Prisoners & 0.26 & 0.22 & 0.44 & 0.21 \\
\hline Incarceration Rate (per 100k) & 82.66 & 40.50 & 97.70 & 77.80 \\
\hline$\%$ Illiterate & 0.10 & 0.11 & 0.22 & 0.07 \\
\hline$\%$ Foreign & 0.14 & 0.10 & 0.07 & 0.16 \\
\hline $\mathrm{N}$ & 339,857 & & 83,045 & 256,812 \\
\hline $\mathrm{N} \dagger$ & 242,061 & & 76,529 & 165,532 \\
\hline \multicolumn{5}{|l|}{ Men } \\
\hline Married & 0.56 & 0.50 & 0.75 & 0.49 \\
\hline Age at 1st Marriage (excl never married) $\dagger$ & 22.56 & 9.36 & 21.92 & 22.92 \\
\hline Never Married & 0.36 & 0.48 & 0.09 & 0.45 \\
\hline Non-White & 0.10 & 0.29 & 0.19 & 0.07 \\
\hline Age & 36.98 & 16.30 & 54.21 & 31.13 \\
\hline Compulsory School & 0.75 & 0.43 & 0.00 & 1.00 \\
\hline Compulsory Cohort (centered) & -15.95 & 23.41 & 14.49 & -26.28 \\
\hline Cohort (5-year intervals) & 1894.93 & 16.29 & 1877.72 & 1900.76 \\
\hline \multicolumn{5}{|l|}{ State of Birth Chars (at age 10) } \\
\hline$\%$ Employed in Manufacturing & 0.07 & 0.05 & 0.04 & 0.08 \\
\hline$\%$ Non-White Prisoners & 0.27 & 0.23 & 0.45 & 0.20 \\
\hline Incarceration Rate (per 100k) & 83.18 & 40.82 & 98.88 & 77.85 \\
\hline$\%$ Illiterate & 0.11 & 0.11 & 0.22 & 0.06 \\
\hline$\%$ Foreign & 0.13 & 0.10 & 0.07 & 0.16 \\
\hline $\mathrm{N}$ & 339,148 & & 85,871 & 253,277 \\
\hline $\mathrm{N} \dagger$ & 216,149 & & 77,953 & 138,196 \\
\hline
\end{tabular}

Source: 1930 Census. Marriage is limited to those married with spouse present. Age at first marriage includes those with spouse present or absent and excludes those never married. 
Table S4: Descriptive Statistics 10-Year Regression Discontinuity Sample - 1910

\begin{tabular}{|c|c|c|c|c|}
\hline & All & Std Dev & Non-Compulsory & Compulsory \\
\hline \multicolumn{5}{|l|}{ Women } \\
\hline Married & 0.57 & 0.50 & 0.59 & 0.54 \\
\hline Age at Current Marriage (excl remarr) $\dagger$ & 21.42 & 4.89 & 21.24 & 21.65 \\
\hline Remarried $t$ & 0.07 & 0.25 & 0.07 & 0.07 \\
\hline Never Married & 0.35 & 0.48 & 0.31 & 0.38 \\
\hline Non-White & 0.09 & 0.29 & 0.14 & 0.04 \\
\hline Age & 31.66 & 12.68 & 32.51 & 30.65 \\
\hline Compulsory School & 0.46 & 0.50 & 0.00 & 1.00 \\
\hline Compulsory Cohort (centered) & 0.05 & 5.68 & 4.53 & -5.26 \\
\hline Cohort (5-yr intervals) & 1880.23 & 12.69 & 1879.41 & 1881.21 \\
\hline \multicolumn{5}{|l|}{ State of Birth Chars (@ age 10) } \\
\hline$\%$ Employed in Manufacturing & 0.06 & 0.04 & 0.05 & 0.08 \\
\hline$\%$ Non-White Prisoners & 0.25 & 0.22 & 0.31 & 0.17 \\
\hline Incarceration Rate (per 100k) & 89.20 & 40.83 & 88.23 & 90.35 \\
\hline$\%$ Illiterate & 0.12 & 0.08 & 0.14 & 0.09 \\
\hline$\%$ Foreign & 0.13 & 0.09 & 0.11 & 0.15 \\
\hline $\mathrm{N}$ & 76,770 & & 41,619 & 35,151 \\
\hline $\mathrm{N}^{+}$ & 40,568 & & 22,783 & 17,785 \\
\hline $\mathrm{N} t$ & 43,605 & & 24,529 & 19,076 \\
\hline \multicolumn{5}{|l|}{ Men } \\
\hline Married & 0.49 & 0.50 & 0.52 & 0.46 \\
\hline Age at Current Marriage (excl remarr) $\dagger$ & 25.20 & 5.27 & 25.04 & 25.40 \\
\hline Remarried $\ddagger$ & 0.08 & 0.27 & 0.08 & 0.07 \\
\hline Never Married & 0.46 & 0.50 & 0.42 & 0.50 \\
\hline Non-White & 0.08 & 0.28 & 0.12 & 0.04 \\
\hline Age & 32.03 & 12.60 & 33.06 & 30.83 \\
\hline Compulsory School & 0.46 & 0.50 & 0.00 & 1.00 \\
\hline Compulsory Cohort (centered) & -0.04 & 5.68 & 4.50 & -5.30 \\
\hline Cohort (5-yr intervals) & 1879.88 & 12.62 & 1878.87 & 1881.05 \\
\hline \multicolumn{5}{|l|}{ State of Birth Chars (@ age 10) } \\
\hline$\%$ Employed in Manufacturing & 0.06 & 0.04 & 0.05 & 0.08 \\
\hline$\%$ Non-White Prisoners & 0.24 & 0.22 & 0.30 & 0.17 \\
\hline Incarceration Rate (per 100k) & 89.11 & 40.87 & 88.00 & 90.41 \\
\hline$\%$ Illiterate & 0.11 & 0.08 & 0.14 & 0.08 \\
\hline$\%$ Foreign & 0.13 & 0.09 & 0.11 & 0.15 \\
\hline $\mathrm{N}$ & 77,874 & & 41,804 & 36,070 \\
\hline $\mathrm{N}^{+}$ & 35,511 & & 19,960 & 15,551 \\
\hline $\mathrm{N} t$ & 38,532 & & 21,809 & 16,723 \\
\hline
\end{tabular}

Source: 1910 Census, limited to those within 10 years of compulsory school cutoff. Marriage is limited to those married with spouse present. Age at current marriage includes those married with spouse present or absent, but excludes those who are remarried. For those who are married (spouse present or absent), remarried indicates whether the current marriage is a remarriage. 
Table S5: Descriptive Statistics 10-Year Regression Discontinuity Sample - 1930

\begin{tabular}{|c|c|c|c|c|}
\hline & All & Std Dev & Non-Compulsory & Compulsory \\
\hline \multicolumn{5}{|l|}{ Women } \\
\hline Married & 0.68 & 0.46 & 0.69 & 0.68 \\
\hline Age at 1st Marriage (excl never married) $\dagger$ & 17.70 & 9.76 & 17.22 & 18.08 \\
\hline Never Married & 0.13 & 0.34 & 0.09 & 0.16 \\
\hline Non-White & 0.16 & 0.37 & 0.16 & 0.16 \\
\hline Age & 42.44 & 14.28 & 47.34 & 38.99 \\
\hline Compulsory School & 0.59 & 0.49 & 0.00 & 1.00 \\
\hline Compulsory Cohort (centered) & -1.67 & 5.67 & 4.16 & -5.77 \\
\hline Cohort (5-year intervals) & 1889.51 & 14.37 & 1884.60 & 1892.96 \\
\hline \multicolumn{5}{|l|}{ State of Birth Chars (@ age 10) } \\
\hline$\%$ Employed in Manufacturing & 0.05 & 0.03 & 0.05 & 0.06 \\
\hline$\%$ Non-White Prisoners & 0.33 & 0.23 & 0.36 & 0.31 \\
\hline Incarceration Rate (per 100k) & 85.42 & 36.43 & 88.94 & 82.94 \\
\hline$\%$ Illiterate & 0.13 & 0.08 & 0.15 & 0.11 \\
\hline$\%$ Foreign & 0.09 & 0.08 & 0.09 & 0.10 \\
\hline $\mathrm{N}$ & 86,585 & & 35,763 & 50,822 \\
\hline $\mathrm{N} \dagger$ & 75,103 & & 32,543 & 42,560 \\
\hline \multicolumn{5}{|l|}{ Men } \\
\hline Married & 0.71 & 0.45 & 0.76 & 0.68 \\
\hline Age at 1 st Marriage (excl never married) $\dagger$ & 22.66 & 9.38 & 22.67 & 22.65 \\
\hline Never Married & 0.18 & 0.39 & 0.12 & 0.23 \\
\hline Non-White & 0.15 & 0.36 & 0.16 & 0.15 \\
\hline Age & 42.62 & 14.08 & 47.34 & 39.25 \\
\hline Compulsory School & 0.58 & 0.49 & 0.00 & 1.00 \\
\hline Compulsory Cohort (centered) & -1.60 & 5.68 & 4.19 & -5.75 \\
\hline Cohort (5-year intervals) & 1889.34 & 14.16 & 1884.61 & 1892.72 \\
\hline \multicolumn{5}{|l|}{ State of Birth Chars (@ age 10) } \\
\hline$\%$ Employed in Manufacturing & 0.05 & 0.03 & 0.05 & 0.06 \\
\hline$\%$ Non-White Prisoners & 0.33 & 0.23 & 0.36 & 0.31 \\
\hline Incarceration Rate (per 100k) & 85.19 & 36.18 & 88.41 & 82.88 \\
\hline$\%$ Illiterate & 0.13 & 0.08 & 0.15 & 0.11 \\
\hline$\%$ Foreign & 0.09 & 0.08 & 0.09 & 0.10 \\
\hline $\mathrm{N}$ & 85,692 & & 35,739 & 49,953 \\
\hline $\mathrm{N} \dagger$ & 69,991 & & 31,588 & 38,403 \\
\hline
\end{tabular}

Source: 1930 Census, limited to those within 10 years of compulsory school cutoff. Marriage is limited to those married with spouse present. Age at first marriage includes those with spouse present or absent and excludes those never married. 
Table S6: Coefficients from Models Predicting Marital Status - 1910

Panel A: Full Sample

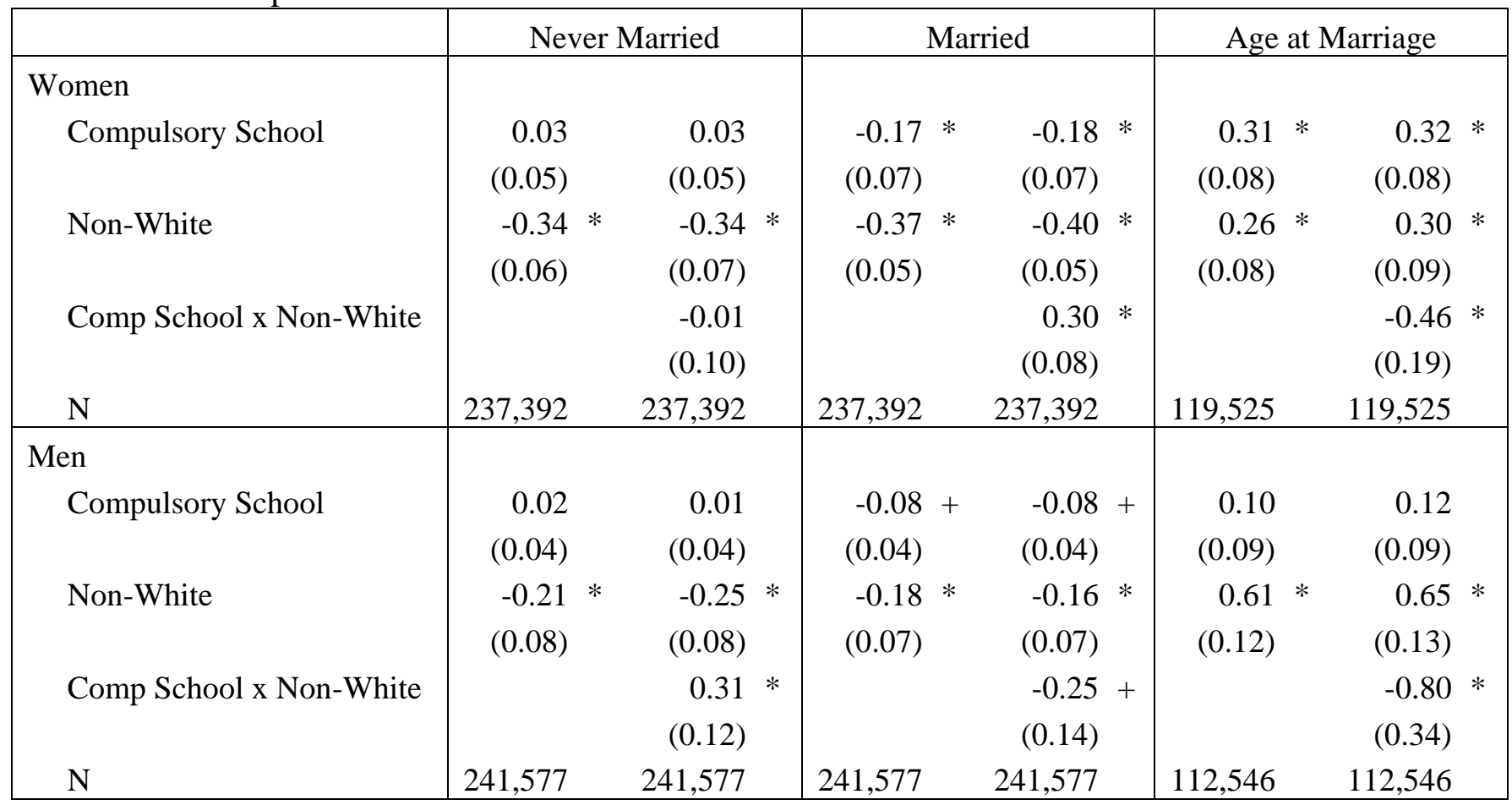

Panel B: 10-Year Regression Discontinuity Sample

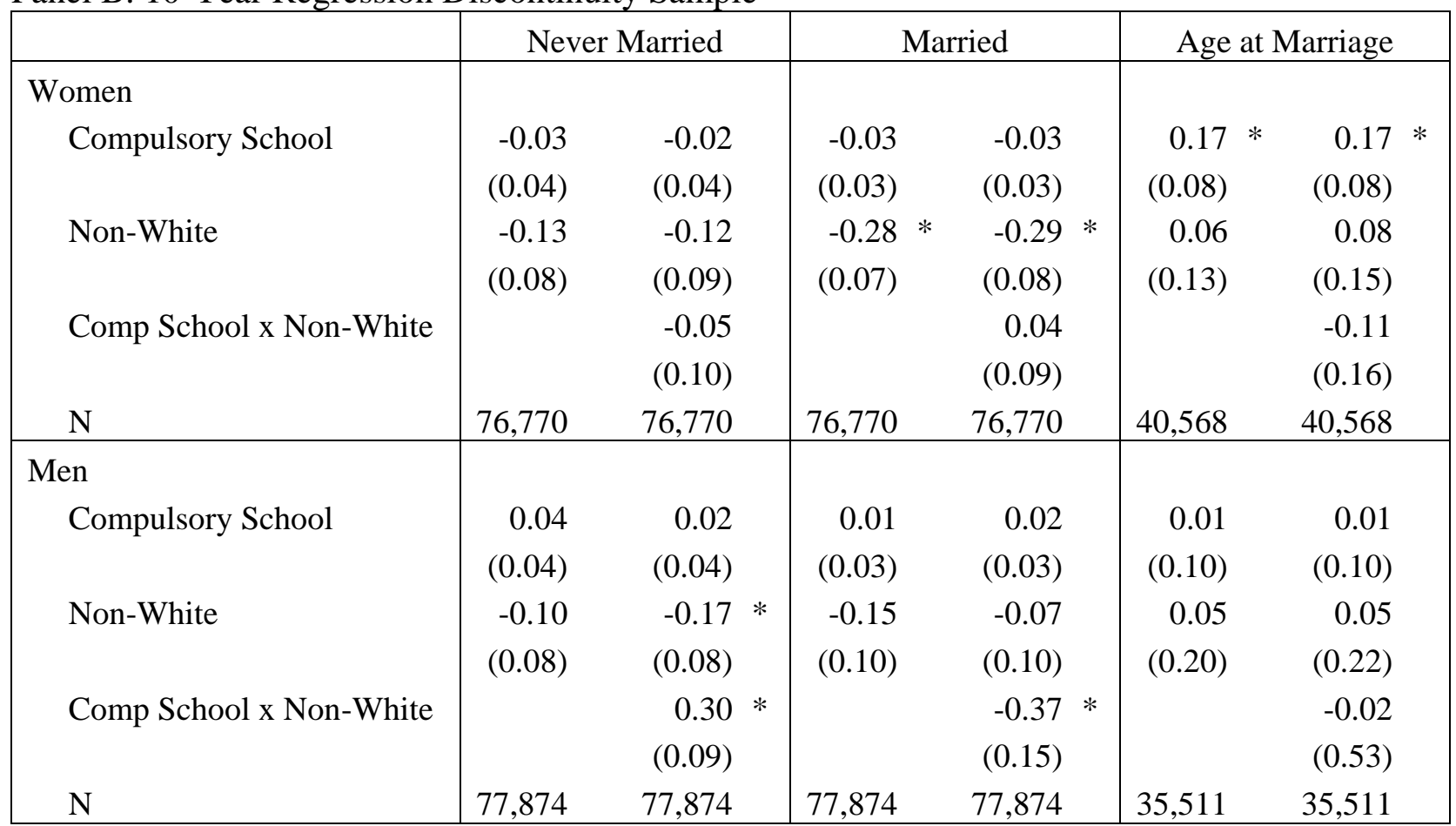

Source: 1910 Census. ${ }^{*} \mathrm{p}<0.05 ;+\mathrm{p}<0.10$ Robust standard errors adjusted for state-level clustering are in parentheses.

Panel B sample is limited to those ten years on each side of the compulsory assignment cutoff. Models include controls for age at time of the law (the assignment variable) and its interaction with compulsory assignment, age up to a quartic, cohort (in five year intervals), state of birth, and state characteristics that best explain state 
variation in timing of compulsory attendance laws (\% manufacturing employment, $\%$ non-white prisoners, incarceration rate, $\%$ illiterate, $\%$ foreign). Models predicting age at marriage also control for never married. Coefficients for married and never married are from logit models. 
Table S7: Coefficients from Models Predicting Marital Status - 1930

Panel A: Full Sample

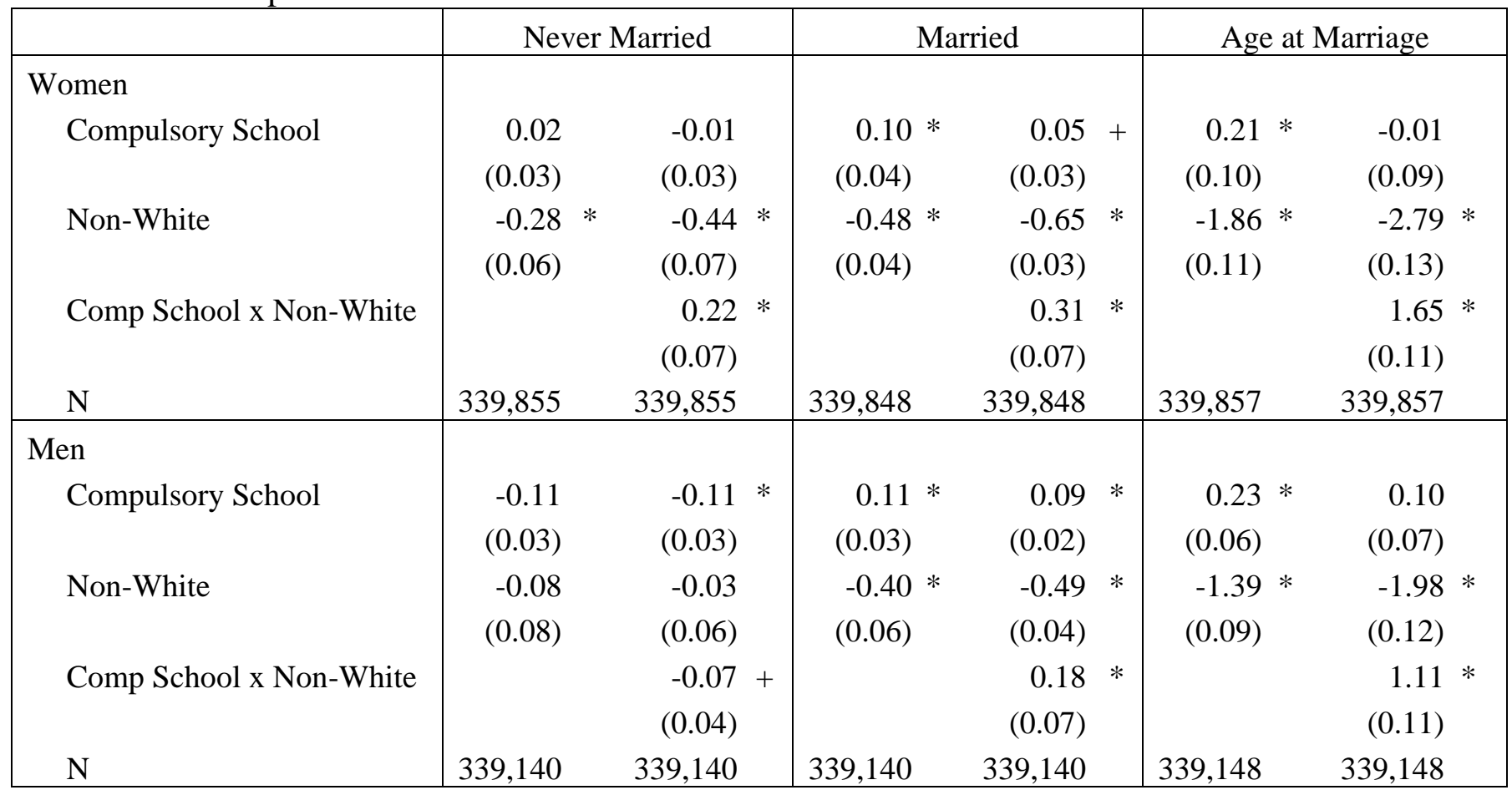

Panel B: 10-Year Regression Discontinuity Sample

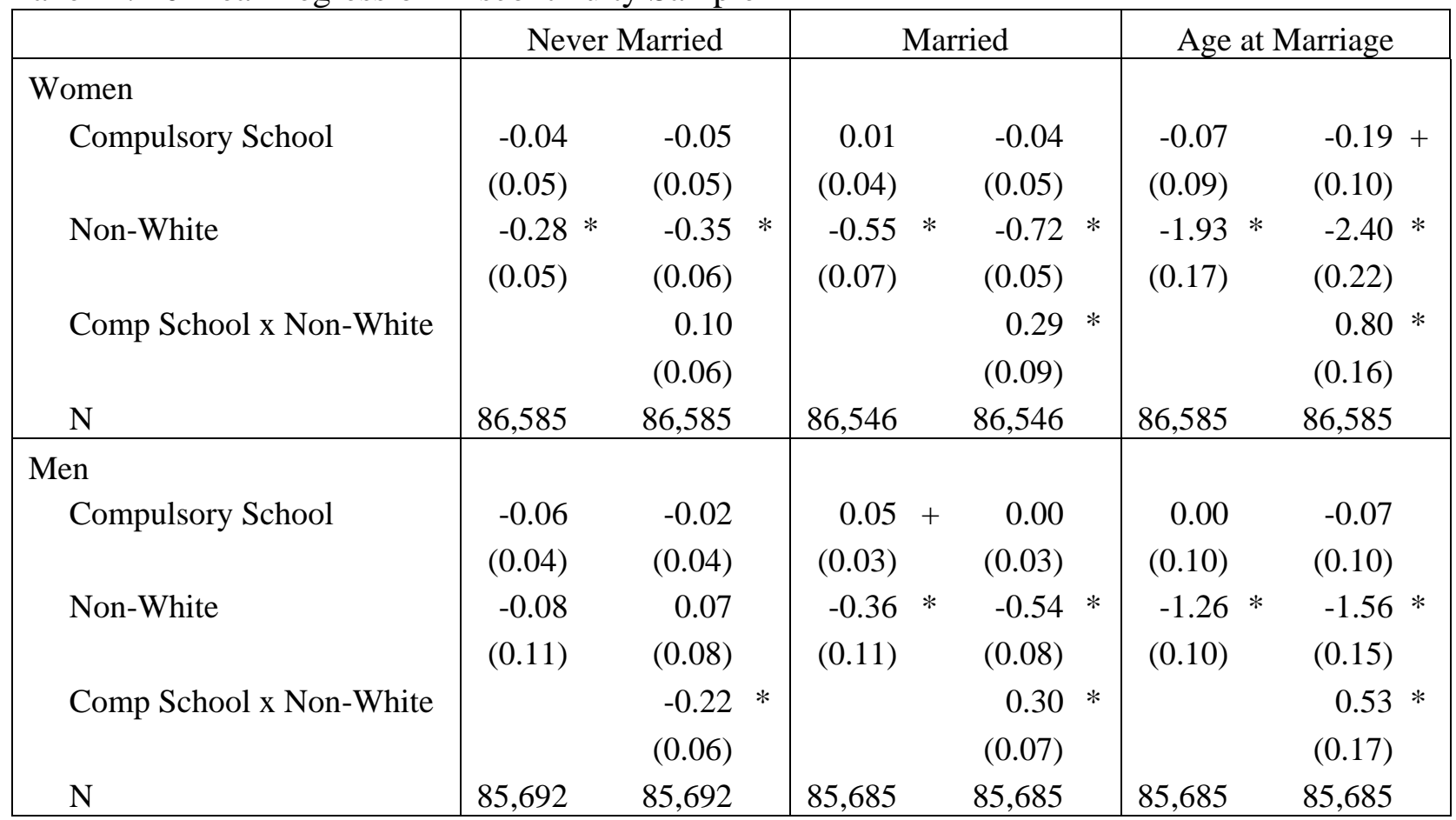

Source: 1930 Census. $* \mathrm{p}<0.05 ;+\mathrm{p}<0.10$ Robust standard errors adjusted for state-level clustering are in parentheses.

Panel B sample is limited to those ten years on each side of the compulsory assignment cutoff. Models include controls for age at time of the law (the assignment variable) and its interaction with compulsory assignment, age up to a quartic, cohort (in five year intervals), state of birth, and state characteristics that best explain state 
variation in timing of compulsory attendance laws (\% manufacturing employment, $\%$ non-white prisoners, incarceration rate, $\%$ illiterate, $\%$ foreign). Models predicting age at marriage also control for never married. Coefficients for married and never married are from logit models. 
Table S8: Coefficients from 5-Year Regression Discontinuity Models Predicting Marital Status in 1910 - Logit Models to Predict Binary Outcomes

\begin{tabular}{|l|rr|rr|}
\hline & \multicolumn{3}{|c|}{ Never Married } & \multicolumn{2}{c|}{ Married } \\
\hline Women & & & & \\
Compulsory School & -0.03 & -0.03 & 0.01 & 0.01 \\
& $(0.05)$ & $(0.05)$ & $(0.04)$ & $(0.04)$ \\
Non-White & -0.09 & -0.09 & $-0.28 * *$ & $-0.27 * *$ \\
& $(0.10)$ & $(0.11)$ & $(0.09)$ & $(0.09)$ \\
Comp School x Non-White & & 0.00 & & -0.01 \\
& & $(0.13)$ & & $(0.11)$ \\
N & 39,499 & 39,499 & 39,499 & 39,499 \\
\hline Men & & & & \\
Compulsory School & 0.08 & 0.07 & -0.01 & 0.00 \\
& $(0.06)$ & $(0.06)$ & $(0.05)$ & $(0.05)$ \\
Non-White & 0.00 & -0.09 & -0.26 & -0.14 \\
& $(0.11)$ & $(0.10)$ & $(0.14)$ & $(0.14)$ \\
Comp School x Non-White & \multicolumn{3}{|c|}{$0.28 * *$} & -0.36 \\
& & $(0.10)$ & & $(0.16)$ \\
N & 39,913 & 39,913 & 39,913 & 39,913 \\
\hline
\end{tabular}

Source: 1910 Census. $* \mathrm{p}<0.05 ;+\mathrm{p}<0.10$ Robust standard errors adjusted for state-level clustering are in parentheses. Sample is limited to those five years on each side of the compulsory assignment cutoff. Models include controls for age at time of the law (the assignment variable) and its interaction with compulsory assignment, age up to a quartic, cohort (in five year intervals), state of birth, and state characteristics that best explain state variation in timing of compulsory attendance laws (\% manufacturing employment, $\%$ non-white prisoners, incarceration rate, $\%$ illiterate, $\%$ foreign). 
Table S9: Coefficients from 5-Year Regression Discontinuity Models Predicting Marital Status in 1930 - Logit Models to Predict Binary Outcomes

\begin{tabular}{|c|c|c|c|c|}
\hline \multirow{3}{*}{$\begin{array}{l}\text { Women } \\
\text { Comp }\end{array}$} & \multicolumn{2}{|c|}{ Never Married } & \multicolumn{2}{|c|}{ Married } \\
\hline & & & & \\
\hline & $\begin{array}{r}-0.10 \\
(0.07)\end{array}$ & $\begin{array}{l}-0.12+ \\
(0.07)\end{array}$ & $\begin{array}{r}0.00 \\
(0.06)\end{array}$ & $\begin{array}{r}-0.04 \\
(0.06)\end{array}$ \\
\hline Non-White & $\begin{array}{l}-0.31 \quad * * \\
(0.05)\end{array}$ & $\begin{array}{l}-0.38 * * \\
(0.09)\end{array}$ & $\begin{array}{l}-0.61 \text { ** } \\
(0.07)\end{array}$ & $\begin{array}{l}-0.72{ }^{* *} \\
(0.04)\end{array}$ \\
\hline Comp School x Non-White & & $\begin{array}{r}0.12 \\
(0.08)\end{array}$ & & $\begin{array}{c}0.21 \\
(0.09)\end{array}$ \\
\hline $\mathrm{N}$ & 43,123 & 43,123 & 43,115 & 43,115 \\
\hline Men & & & & \\
\hline Compulsory School & $\begin{array}{r}-0.03 \\
(0.06)\end{array}$ & $\begin{array}{r}0.00 \\
(0.06)\end{array}$ & $\begin{array}{r}0.06 \\
(0.05)\end{array}$ & $\begin{array}{r}0.02 \\
(0.05)\end{array}$ \\
\hline Non-White & $\begin{array}{r}-0.06 \\
(0.15)\end{array}$ & $\begin{array}{r}0.05 \\
(0.12)\end{array}$ & $\begin{array}{l}-0.39 \text { ** } \\
(0.14)\end{array}$ & $\begin{array}{l}-0.53 \text { ** } \\
(0.11)\end{array}$ \\
\hline Comp School x Non-White & & $\begin{array}{l}-0.19 * \\
(0.09)\end{array}$ & & $\begin{array}{l}0.25 \text { ** } \\
(0.09)\end{array}$ \\
\hline $\mathrm{N}$ & 42.714 & 42.714 & 42.725 & 42,725 \\
\hline
\end{tabular}

Source: 1930 Census. $* \mathrm{p}<0.05 ;+\mathrm{p}<0.10$ Robust standard errors adjusted for state-level clustering are in parentheses. Sample is limited to those five years on each side of the compulsory assignment cutoff. Models include controls for age at time of the law (the assignment variable) and its interaction with compulsory assignment, age up to a quartic, cohort (in five year intervals), state of birth, and state characteristics that best explain state variation in timing of compulsory attendance laws (\% manufacturing employment, $\%$ non-white prisoners, incarceration rate, $\%$ illiterate, $\%$ foreign). 
Figures Checking for Discontinuities

Figure S1: Frequency by Age at Time of Compulsory Law - 1910

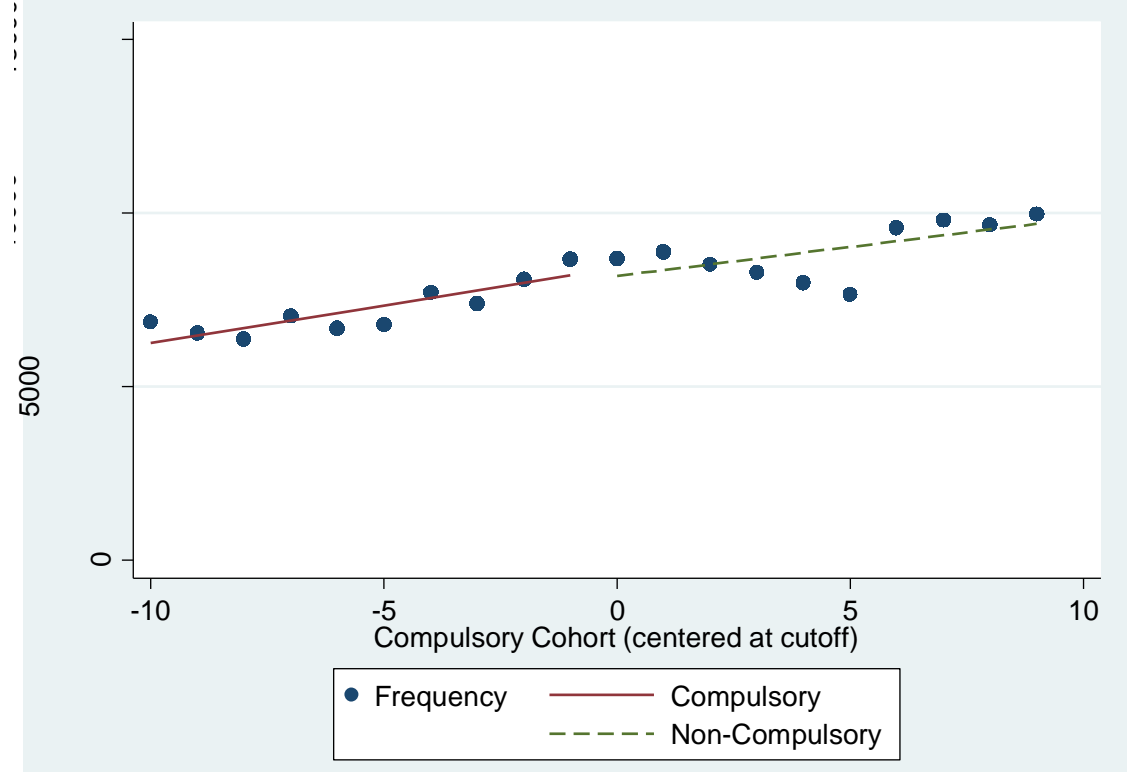

Figure S2: Frequency by Age at Time of Compulsory Law - 1930

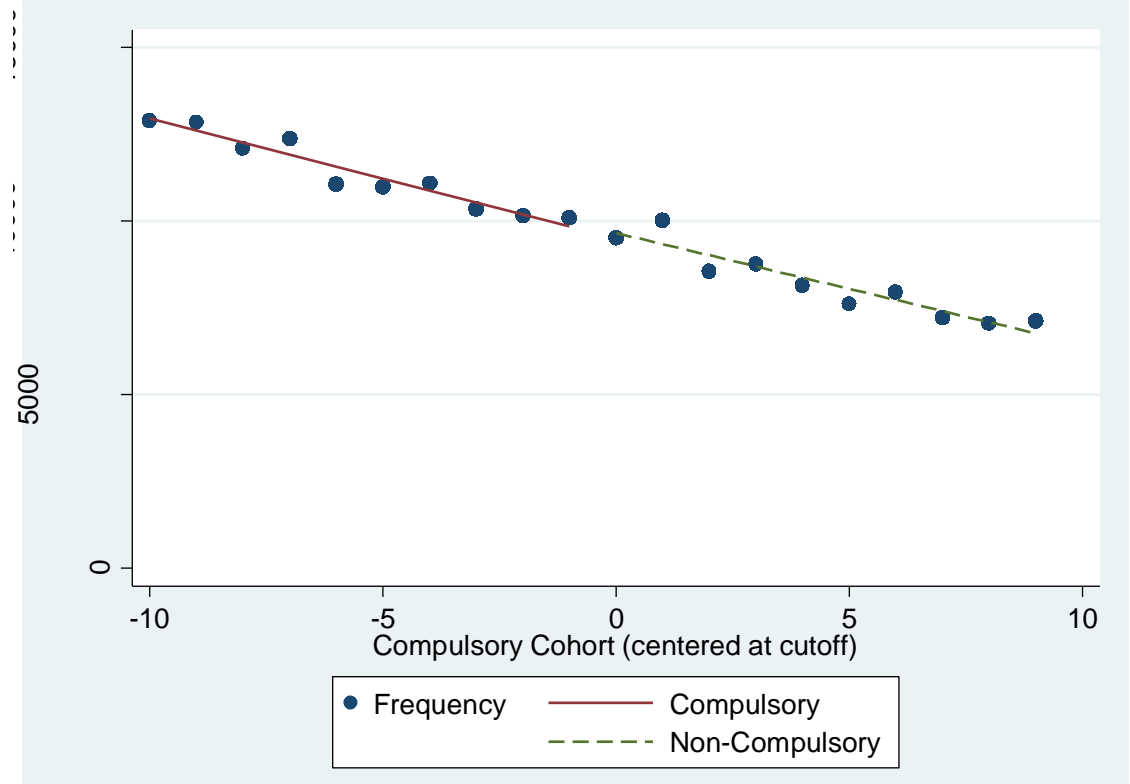


Figure S3: Proportion Foreign Born by Age at Time of the Compulsory Law - 1910

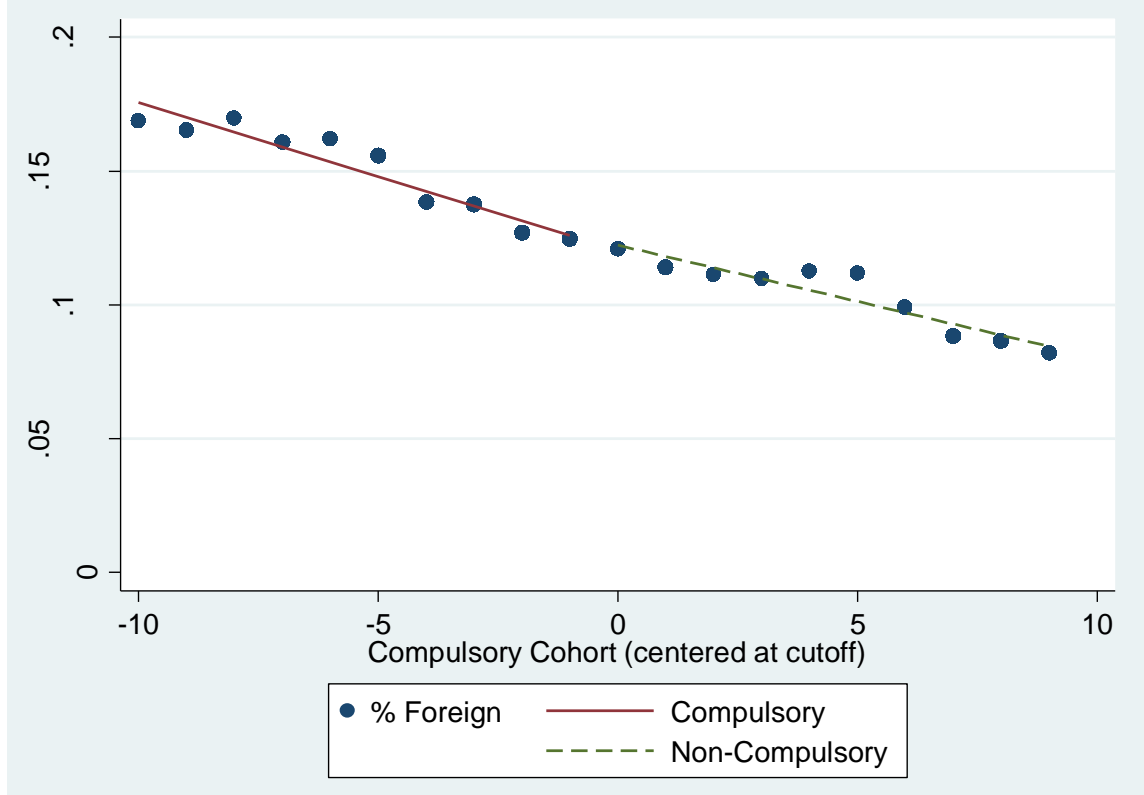

Figure S4: Proportion Foreign Born by Age at Time of the Compulsory Law - 1930

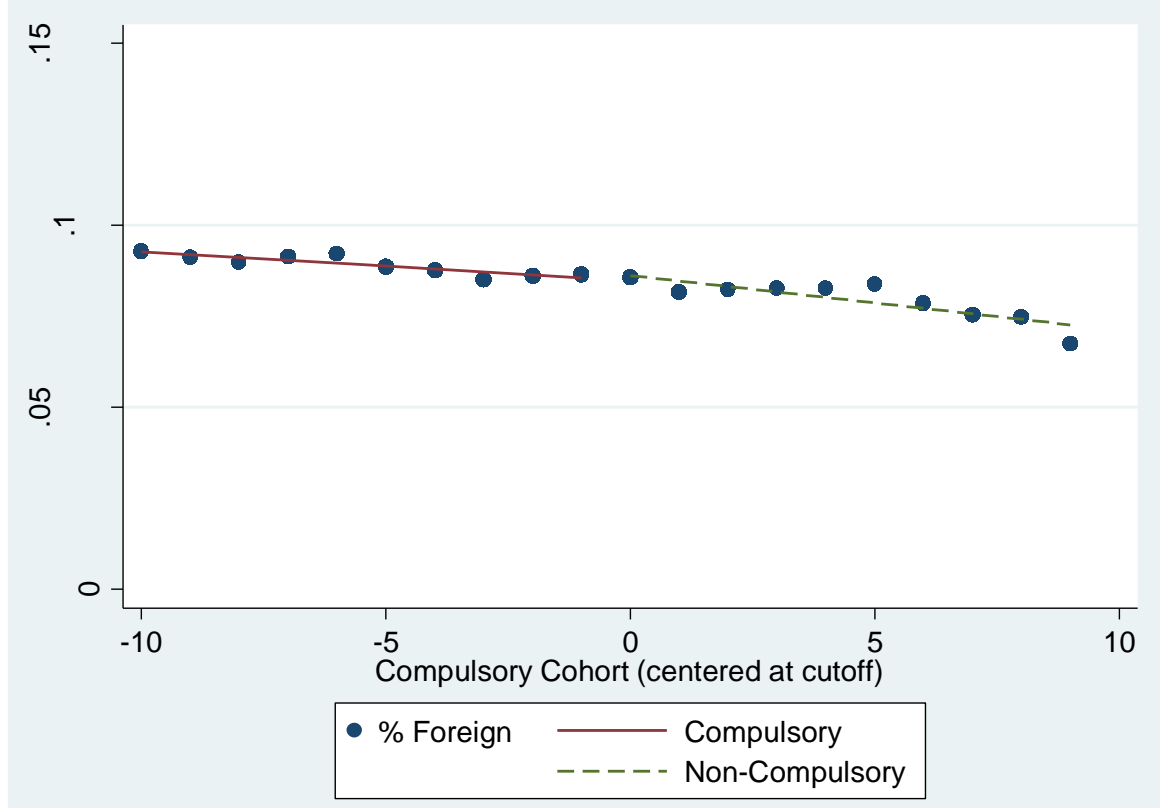


Figure S5: Proportion Employed in Manufacturing by Age at Compulsory Law - 1910

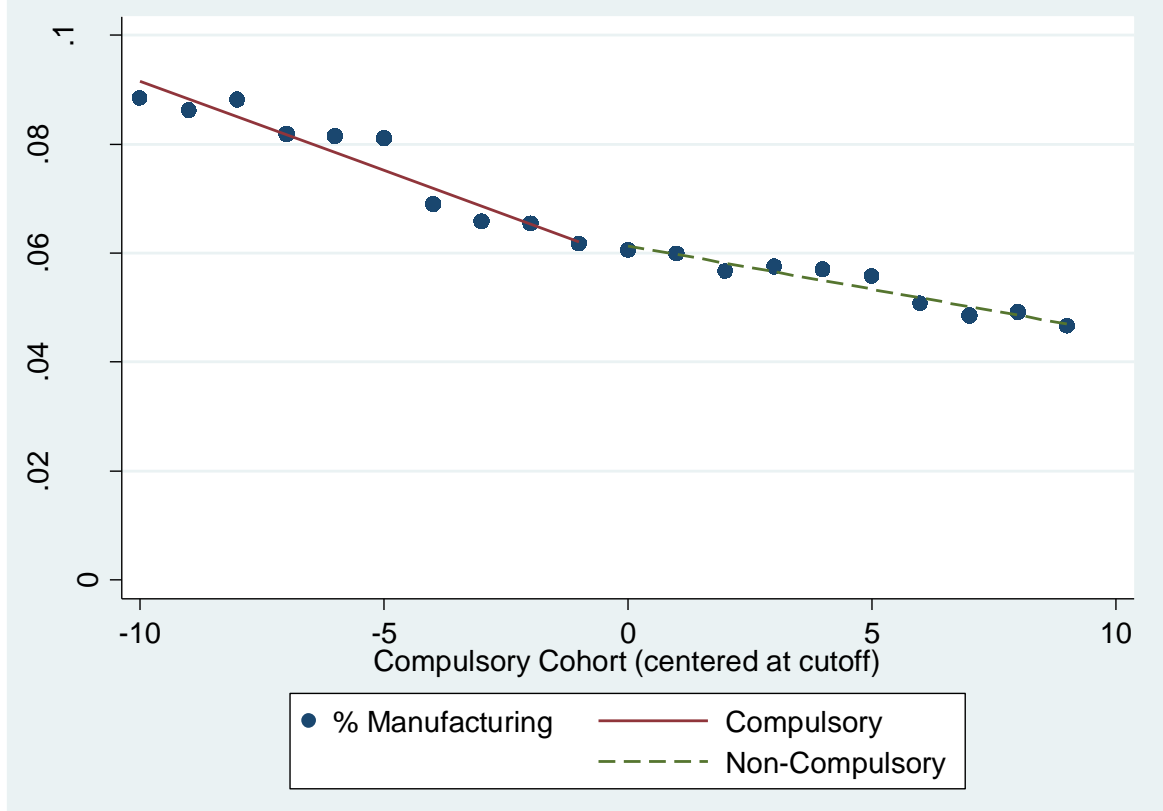

Figure S6: Proportion Employed in Manufacturing by Age at Compulsory Law - 1930

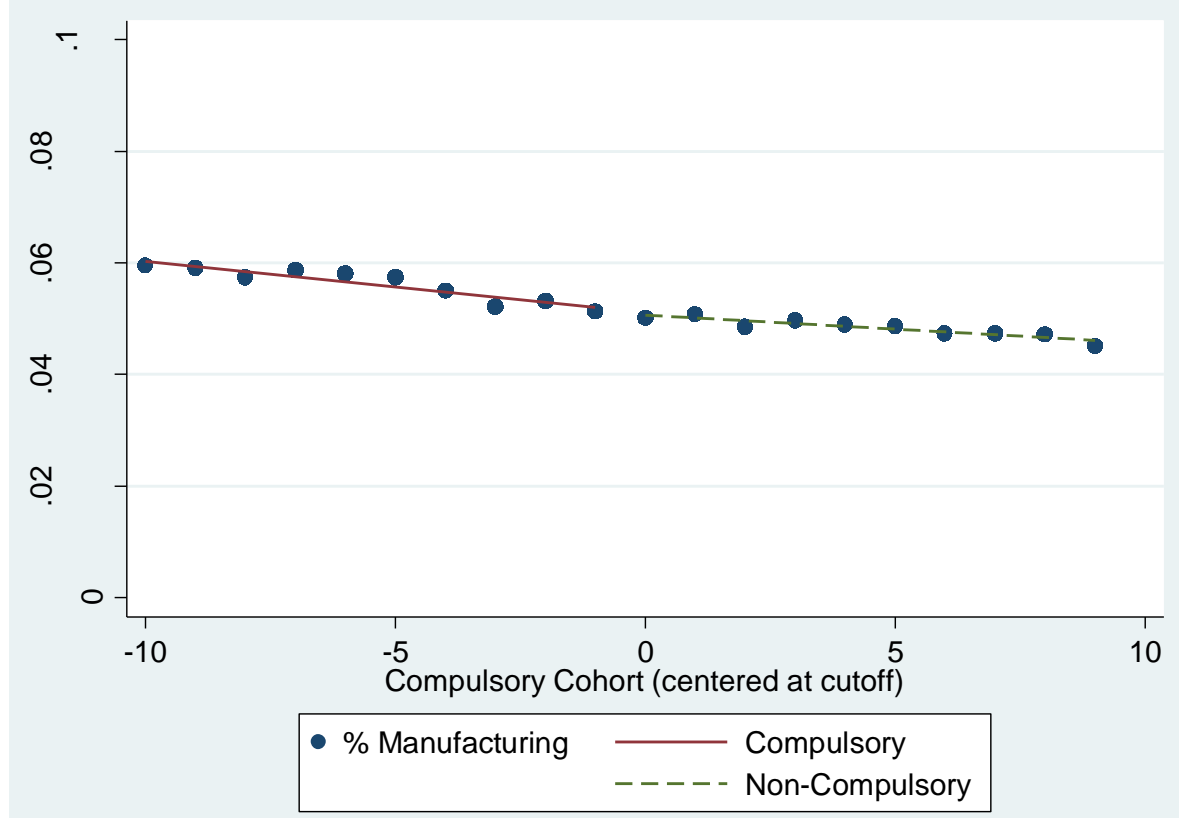

